\title{
Textual Artifact of Advertising: A Thrust of Halliday's Mood System Resources
}

\section{Artefato textual da publicidade: um impulso dos recursos do sistema de tom de Halliday}

\author{
Taofeek O. Dalamu* \\ *Anchor University, Lagos / Nigeria \\ tdalamu@aul.edu.ng \\ http:/ / orcid.org/0000-0002-5494-4854
}

\begin{abstract}
This paper argued that advertising contains variegated texts that theoretical terminologies are capable of exemplifying. Thus, ten beverage advertisements, among other types were chosen for analysis. Halliday's mood exchange resources decomposed the texts into meaningful components, which were further calculated with tables and graphs. The calibration indicated that Complement (official milk, Uncle Thomas), Adjunct (with *826\#, of Akwa Ibom), and Predicator (Dial, Drink) were dominant grammatical forms of semiosis sometimes appearing without the Subject and Finite elements. Moreover, the examination revealed exchanges initiated in the "interactions" as operating in the spheres of half-constitutive and half-ancillary organs that are significantly associated with socio-cultural norms. Prominent in the text were features of products, personal benefits and textual exaltations. Theoretical mediums, as this study suggests, would serve to uncover communication details to influence the authorities on advertising regulations.
\end{abstract}

KEYWORDS: advertising communication; artifact; Mood System; specimen; text.

RESUMO: Este artigo argumenta que a publicidade contém uma variedade de textos que terminologias teóricas são capazes de exemplificar. Assim, dez propagandas de bebidas, entre outros tipos, foram escolhidas para análise. Os recursos de mudança de tom de Halliday decompuseram os textos em componentes significativos, que posteriormente foram tabulados com tabelas e gráficos. A calibragem indicou complementos (leite oficial, Uncle Thomas), adjunto (com *826\#, de Akwa Ibom, e predicado (ligar, beber) foram formas gramaticais de semiose dominantes, por vezes aparecendo sem sujeito e sem elementos finitos. Além disso, a análise indicou que as mudanças iniciadas nas "interações" operavam nas esferas de órgãos meio-constitutivos e meioauxiliares que são significativamente associados a normas socioculturais. Destacam-se no texto as características dos produtos, benefícios pessoais e 
exaltações textuais. Meios teóricos, como sugerido por este estudo, poderiam ser utilizados para revelar os detalhes da comunicação para influenciar as autoridades sobre a regulamentação da publicidade.

PALAVRAS-CHAVE: comunicação publicitária; artefato; Sistema de tom; amostra; texto.

\section{Introduction}

Communication in advertising is an embodiment of text, picture, and color. In Kress' (2010) multimodality theorization, these communication elements are labeled as modes. Thus, modes, following Jewitt's (2009) perspective, are social semiotic channels of representing information, culturally articulated as meaning-making resources. In other words, the entities of modes, operating, for example, as text, image, and color, contribute immensely to meaning-making potential in the advertising plate (JEWITT; BEZEMER; O'HALLORAN, 2016). Given this belief, either the text or image may share similar contributions to the sensitizing event or that the text can express the meaning of the image through the deposition of the text's semantic implications. In this sense, there is an intersectional interaction between the verbal and non-verbal elements. Forceville (1996) explains the two relative perspectives as either a relaying operation or an anchoring function. The notion of artifact, considering the text as an anchorage element, therefore becomes an object of relevance in the present scientific inquiry. Thus, by artifact, the investigation points to the production of wordings and images in advertising as an instance of language to make meanings (HALLIDAY; MATTHIESSEN, 2004) to the audience within the climate of propagated pieces of information.

The terminology of artifact positions the text as an object in the domain of expertise to communicate meaning to readers. Nonetheless, such meaning could be explored again through the same device known as text. Halliday and Matthiessen (2014) observe such situational responsibility ascribed to text as functioning in the hemisphere of specimen. Labeling the text as a specimen, as shown in Figure 1, means that the communicating object is instrumental to the analyst's channel of generating meaning from a message. In that regard, the analyst understands the language employed for the operational cycle before the possibility of meaning potential derivatives. As a result of the "comprehensive" knowledge, the text becomes an 
instrument or tool deployed to execute linguistic communicative activities. The text operating as the analytical facility assists the observer, in Halliday and Matthiessen's $(2004$, p. 3) point of view, to ask questions about:

Why does the text mean what it does (to me, or anyone else)? Why is it valued as it is? Focusing on text as an instrument, the grammarian will be asking what the text reveals about the system of the language in which it is $(\ldots)$ written.

The reception of the text informs the analyst to construct a number of questions about its nature and sequential choice of organization and meaning. It then suggests that anyone who does not have "adequate" knowledge of a language use in a circumstance might find it difficult to neither construct a theory for its exploration nor apply a propounded theoretical concept to analyze an instance of language use. The ideas of competence and performance, explained by Chomsky (1965), are probable terms that soothe the effectiveness of the text as the artifact and the specimen (CHOMSKY, 1965; RICHARDS; PLATT; WEBER, 1997; DE BEAUGRANDE, 1991; MALMKJAER, 2004).

One could then argue that the text as artifact and the text as specimen are two bed-fellows, playing complementary roles in a communicative context. The deduction of meaning potential from the text, as Halliday and Matthiessen (2014) emphasize, attracts the application of a linguistic system. In other words, a linguistic facility is responsible for meaning generation of textual entities. As demonstrated in Figure 1 below, it is on that note that Systemic Functional Linguistics (SFL) has turned to a theory of text (HALLIDAY; MATTHIESSEN, 1997). That map in Figure 1 explains "an" expository environment where an analyst transforms the text in order to illuminate the grammatical semiosis (i.e. making and understanding of meaning) of language. 
FIGURE 1 - Illuminating Text as the crux of meaning potential

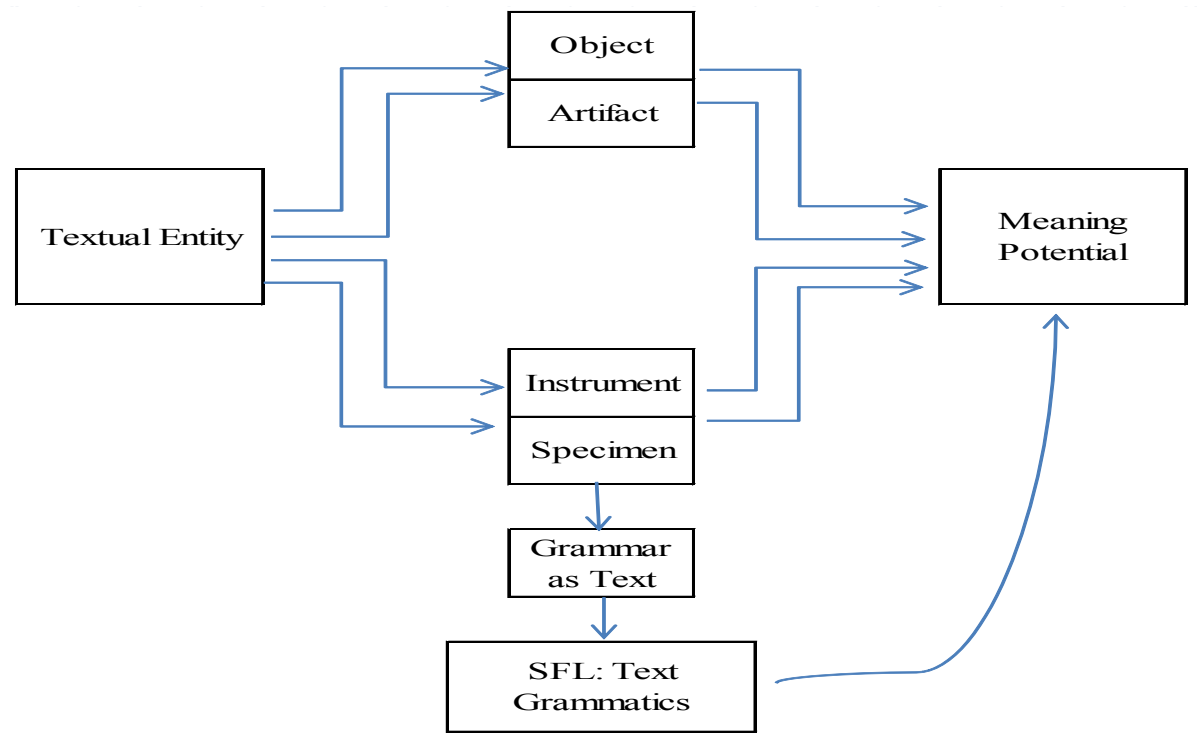

It is probably on the basis of Figure 1 above that Halliday and Matthiessen (1997) conceptualize the theory of language as "grammatics" (HALLIDAY; MATTHIESSEN, 2004, 2014). The use of the linguistic interpretative system (SFL) that invariably informs one to understand what the text means and the cause for the meaning that it reveals.

The instance of language use in this course, as mentioned earlier, is advertising. Advertising is a text with a particular system of communication, unveiled through the structural grammar of its wordings and images. The mood system accommodates some resources for elucidating the text. In simple terms, advertising is the artifact, that is, a product of human conception in a certain context, while the mood system from Halliday's school of thought is the specimen as illustrated in Figure 1. Therefore, one could argue that Halliday's (1995) concept of the mood system is a useful theoretical (textual) entity that has the capacity to explore hidden meaning potential in advertising texts.

Consequently, a text, in Halliday's (2002) approach, entwines with ideational, interpersonal and textual metafunctions. The ideational metafunction provides the content in terms of processes, participants, and circumstances, whereas the logical relations operates as connectors. The interpersonal metafunction provides the interaction within the climate of 
mood, modality, person, polarity, attitude, comment, etc. (MARTIN; ROSE, 2005). The textual metafunction pinpoints the organization of the thematic and informational prominence, while the grammatical and lexical cohesion appear among the textual segments. The feature of the text is its pattern of selections in these various functions and the way that the facilities are combined into a single meaningful whole (HALLIDAY, 2002, p. 230). The functional quality of a text is closely related to an analogous characteristic of the clause, as well as one that is coded in the lexicogrammatical system. As a result, a clause has some functions, realized by the mood system. The speech functions of the clause are statement, question, command, and offer. Thompson (2004) represents these communicative devices by the grammatical categories of declarative, interrogative, and imperative, as well as modulated interogative (see also EGGINS; SLADE, 1997). These categories are the "rhetorical functions of the clause" (HALLIDAY, 2002, p. 233).

The Interpersonal organizational pattern of a clause includes a modal structure (mood, modality, and key), which expresses its character as a speech event. The basic speech functions of statement, question, response, command, and exclamation fall within this category. Sweet (1891) expresses the grammatical system of mood with the principal options of declarative, interrogative (yes / no and wh-types), and imperative. For instance, the difference between she can and can she? is a difference in the communication role adopted by the speaker in his/her interaction with a listener. Actually, just as the logical subject is a function defined by transitivity, so the grammatical subject is a function defined by mood (HALLIDAY, 2002, p. 189).

The goal of this study is to contribute to earlier works on the structure and language of advertising such as that found in Leech (1966), Geis (1982), Cook (2001), Gieszinger (2001), and Goddard (2002). However, the investigation focuses on advertising artifacts from a novel spatial breadth of the Nigerian context. I have approached the exploration by exemplifying the following questions: What are the levels of lexemic density deployed in the advertising frameworks? What is the nature of the role initiatives in the advertising communications? What are the contextual devices represented as persuasive facilities in the advertising discourse? How have the advertising professionals created intersectional interactions between verbal and nonverbal texts? 


\subsection{Text, a Component of Analysis}

Something invaluable, appreciated in SFL, is text/the text. This is because the text is celebrated as the centrality of meaning development in the systemic analysis. In this light, Bloor and Bloor (2004, p. 15) explain that systemicists "are more likely to arrive at interesting and useful descriptions of English if we investigate authentic texts." An authentic text, in that perspective, is a product of any interactional engagement in a social setting, be it verbal or non-verbal. The communicative event - text - could be in terms of the written, the spoken or the gestural form as deployed to negotiate meaningful thoughts. Eggins (2004, p. 23) claims that the text is an "authentic product of social interaction." This means that texts are not only of different contexts; they are also of different structural facilities performing different functions as determined by users. Halliday and Hasan's (1976) perception of the text in the past is much more relevant today. Thus, Halliday and Hasan (1976, p. 1) describe the text in linguistics' operations as "any passage, spoken or written, of whatever length, that does form a unified whole." The description identifies some properties of the text in relation to the model of discourse, the size of communication, and the completeness of the communicative entity.

Taxonomy may well have been a source of inspiration for Gregory and Carroll (1978) to define the text as a meaningful concept. That comment seems to influence Fairclough (2003), in a broad sense, to say that the text is an instance - order of occurrence - of language in use (p. 3 ), and a semantic fabrication in the sphere of the users' culture (p. 12). In particular, Hoey (2001) expatiates the essence of text as the site of interaction between/among interactants. He explains the text as "the visible evidence of a reasonable self-contained purposeful interaction between one or more writers and one or more readers, in which the writer(s) control the interaction and produce most of (characteristically all) the language" (HOEY, 2001, p. 11; see also FONTAINE, BARTLET'T; O'GRADY, 2013). In that regard, the user does not manufacture the text haphazardly; rather, text is a purposeful object focusing on communicative enterprises. As a semantic device, Halliday and Hasan (1976, p. 26) remark that:

A text, then, can be thought of as the basic unit of meaning in language. It is to semantic structure what the sentence is to lexicogrammatical structure and the syllable to phonological structure. It is a unit of 
situational-semantic organization: a continuum of meaning-in-context, constructed around the semantic relation of cohesion (see also in TSENG, 2008; DALAMU, 2018a).

Thus, it becomes unarguable that the social situation influences the structural configuration of the text as well as its semantic edifice. In support of that, Yule (1986, p. 190) advises that:

It is important not to overlook the social aspect of language because, in many ways, speech is a form of social identity and is used, consciously or unconsciously, to indicate membership of different social groups or different speech communities.

An advertising communication, for instance, in Yule's view, may identify strongly with the community in different social strata. The purpose of this intimate identification could be to easily inspire the target audience. The means of communication used in a community may include different languages, different regional and social dialects of one or more languages, different register, different images, and different channels of communication. In the Nigerian print-media-telecommunications advertisements (henceforth ad/ads), for example, advertising experts creatively construct and publish diverse and new lexicons as generated and published in the daily newspaper often to build relationships with subscribers (DALAMU, 2017a). New words are coined. New codes are configured. New signs are organized as well. A few examples include: ePresence, ur (your), HyNet, Callerztunez, BB (Blackberry), $u$ (you), cr8 (create), gr8 (great), 4 (for), 2 (two or too), and $4 \mathrm{rm}$, (from). All these, as Dalamu (2018b) notes, may sequentially become the language of both the telecommunications operators and their subscribers, having involved the contexts of the people's culture and the business setting.

In contemporary scholarly affairs, the notion of text is multimodal in configuration. Consequently, Halliday and Matthiessen (2014) describe text as an instance of the linguistic system which produces meaning potential to readers. There is an extension of text from being the spoken and written forms of language to other forms of semiotic systems of communication. Consequently, painting, film, music, advertising, and so on are interpretive texts (LEMKE, 1998; O'HALLORAN, 2004; KRESS; VAN LEEUWEN, 2006; KRESS, 2009; BEZEMER; JEWITT, 2010; FORCEVILLE, 
2010). This current status of text is what Kress (2010) recapitulates as the multimodal text, operating as the dominant device in multimodality concepts.

Generally, the environment of the text, one could suggest, operates in two dimensions: internal and external relational fields. The structure of the text is the internal configuration, while the external value relies on the socio-cultural influences. Halliday and Hasan (1976, p. 20) respond to the duality of activities that yields appropriate meanings in the text in the following manner:

Linguistically, the analyst responds to specific features which bind the passage together, the patterns of connection, independent of structure that we are referring to as cohesion. Situationally, the analyst takes into account all he knows of the environment: what is going on, what part is the language playing, who are involved.

The structure is the choice of lexemes that the language users deployed in a communicative field. The situation, as Halliday and Hasan (1976) add, is the probable extra-linguistic parameters that are relevant to the statements of meanings about the organized structures of the language event. (MATTHIESSEN; TERUYA; LAM, 2010; HALLIDAY; MATTHIESSEN, 2014). The social context relates to field of discourse, tenor of discourse, and mode of discourse (MARTIN; ROSE, 2005; THOMPSON, 2014). However, De Beaugrande and Dressler (1981) highlight other features of text as coherence, intentionality, acceptability, informativity, intertextuality (also in WEISSER, 2005).

\subsection{Theoretical Prime}

A ground-laying of communication, one could testify, is to interact between one individual and the other. This essential language characteristic could help the interactant to establish social relationships in one way or another in order to achieve certain things. The involvement of (at least) two communicators in an interactional episode seems to excite Thompson (2014) to argue that communication is innately-unavoidably a two-way systematic activity. As the dialog conveys meaning, Eggins (2004) describes the establishment of the role relationships as an aspect of the text in which the production of meaning is coherent to the exchange. This is due to the complementary roles of meaning that the interactants play. Halliday (1995) 
suggests that the interactants of the exchange are co-authors of the text, that is, the product. Halliday classifies the speaker as performing a role of the seeker of information from the audience, while the audience plays a role of supplier of information to the speaker. That communicative behavior, Halliday and Matthiessen (2004) emphasize, is referred to as an interact, ${ }^{1}$ recognizing giving as receiving and demanding as giving in response.

In the theorization of the exchange module, the interactive process demonstrates a sort of turn-taking normative responsibilities between the addresser and the addressee. It is out of that procedure that Halliday and Matthiessen (2014) deduce two primary but specific domains of relationships of the communicators, which are: the speech roles; and the commodity of the exchange as illustrated in Figure 2 below.

FIGURE 2 - The Semantic system of mood resources (HALLIDAY; MATTHIESSEN, 2014, p. 136)

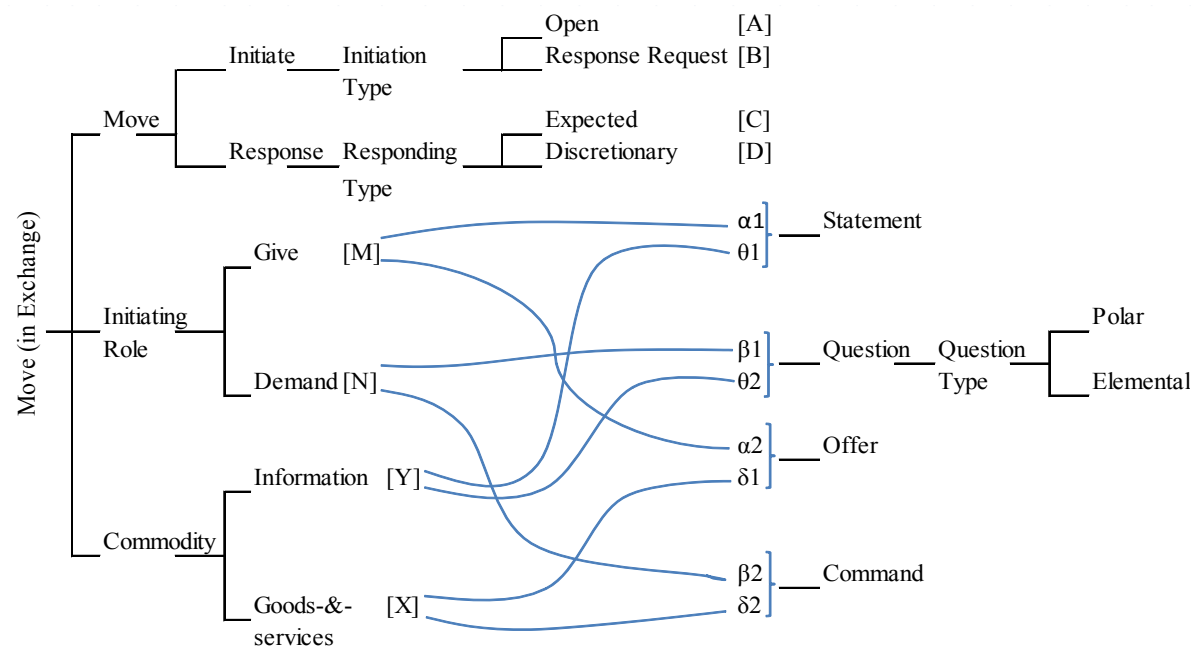

The semantic system of the speech, as shown in Figure 2 above, functions as an adaptation, revealing three arms of the exchange as turntaking roles that the addresser and the addressee perform. The Move positions the addresser as initiating a communicative inquiry that requires a response from the addressee. The initiating role of the addresser could either

\footnotetext{
1 "Interact" is Halliday's (1995) construct, referring to an act of speaking. That is, a communicative exchange between two interactants.
} 
be giving or demanding. This connects the Commodity being exchanged, that is, information or goods-\&-services. These linguistic operations reflect Interpersonal Metafunction, as giving consideration to the meaning of a clause from the spheres of the fundamental types of speech role - giving and demanding. By contrast, the system conceptualizes meaning from the perspective of commodity being exchanged - information and goods-\&services. The synthesis of the role initiation and the commodity of exchange, Ravelli (2000) claims, end up producing four basic speech roles, which are: giving information; demanding information; giving goods- $\&$-services; and demanding goods- $\&$-services. Bloor and Bloor (2013) encapsulate the two formal speech roles as performing constitutive functions as propositions; while the latter two carry out ancillary functions as proposals in the concept of the clause.

SFL labels and enumerates these speech essentials as statement, question, offer, and command (MARTIN, 1992; FONTAINE, 2013). However, the derivatives of the semantic system of mood resources in Figure 2 above could be constructed with the following prescriptive formulae:

Statement $=$ MY: where $\mathrm{M}$ is $\alpha 1$, and $\theta 1$ represents $\mathrm{Y}$

Offer $=\mathrm{MX}$ : where $\mathrm{M}$ is $\alpha 2$, and $\delta 1$ represents $\mathrm{X}$

Question $=\mathrm{NY}$ : where $\mathrm{N}$ is $\beta 1$, and $\theta 2$ represents $\mathrm{Y}$

Command $=\mathrm{NX}$ : where $\mathrm{N}$ is $\beta 2$, and $\delta 2$ represents $\mathrm{X}$.

These combinatory elements, as adapted above, have produced:

$\mathrm{M} \propto 1 . \theta 1 \mathrm{Y}=$ Giving information

$\mathrm{M} \alpha 2 . \delta 1 \mathrm{X}=$ Giving goods- $\&$-services

$\mathrm{N} \beta 1 . \theta 2 \mathrm{Y}=$ Demanding information

$\mathrm{N} \beta 2 . \delta 2 \mathrm{X}=$ Demanding goods- $\&$-services .

Fontaine (2013) expresses the grammatical elements, which operate the four speech role principles as Mood and Residue. Given the circumstances of those two elements, Gerot and Wignell (1994), Butt, Fahey, Spinks and Yallop (1995), and Martin, Matthiessen and Painter (1997) have highlighted Subject, Finite, Predicator, Complement, and Adjunct as devices that facilitate the systemic speech roles' structural, semiosis, and functional 
expositions. Later, the present study will display the application of these linguistic components in the data analysis in Texts 1,2,3-10.

\section{Methodology}

\subsection{Participants}

Mrs. Wumi, 35years, and I collected some ads from The Punch Newspaper ${ }^{\circledR}$ and the Internet at random between July 2016 and January 2017. As the relevance of the choice of The Punch was based on its readership strengths in Nigeria (LEO; NKIRU; ANIEBO, 2015; ASHONG; OGARAKU, 2017), so also, was the choice of the Internet anchored on the proliferation of ads in certain websites such as https://nbplc.com; www. sevenup.org; and https://ibank.fcmb.com during this period. Mrs. Wumi was my ad collection partner because she has always worked with me in assembling ads, taken from their functional sites. In all, we have a collection of 30 ads.

\subsection{Research Design}

This investigation has adopted a sampling procedure, allowing the 30 collected ads to undergo stratification, influencing the final selection of 10 ads meant for analysis.

\subsection{Measurement}

Specifically, I used a Samsung ${ }^{\circledR}$ camera, an Etisalat $^{\circledR}$ modem, and an $H P^{\circledR}$ laptop as the supportive instruments to collect the ads. The camera as used to snap the frameworks of the ads from The Punch, whereas the laptop assisted in downloading the advertising constructions from the Internet through the Etisalat modem. In addition the laptop received the advertising pictures from the camera through Bluetooth ${ }^{\circledR}$, using the Microsoft Picture Manager ${ }^{\mathbb{R}}$ software to adjust the ads to the required patterns and shapes. As stated earlier, the ad collection included 30 pieces. The reason for this number was to ensure openness, user-friendliness, and knowledge of a range of ads that could allow for the appropriate selection of ads relevant to the present study. 


\subsection{Procedure}

I stratified the 30 ads into 10 parts, where one ad in each stratum became a choice in each group. The nature of the relationships and the contents of the multimodal texts were considerable factors of the 10 ads, functioning as the subject of analysis. To reiterate, from the Punch Newspaper and the Internet, I considered 10 ads in the domains of foods and beverages $\left(\right.$ Peak $k^{\circledR}$, Star Lite ${ }^{\circledR}$, Pepsi ${ }^{\circledR}$, Harp $^{\circledR}$, Guinness $^{\circledR}$ and Maltina $\left.{ }^{\circledR}\right)$, finance (Union Bank ${ }^{\circledR}$ and $F C M B^{\circledR}$ ), oil and gas firm $\left(E x \times o n M o b i{ }^{\circledR}\right)$, and telecommunications $\left(\right.$ Airte $\left.^{\mathbb{R}}\right)$ for analysis. In addition, the limitation of the ads' strata to 10 ads was due to appropriateness and to avoid an excessive number of ads that might not contribute critically to this research. It is worth stressing that the fast-moving consumer goods took the lead in the selection of the data given that the food and beverage industry in Nigeria seemingly advertise more products in print than any other industries (GEORGE, 2010).

As shown below, Table 1 presents the verbal elements in their structural forms either as declarative or imperative clauses. The presentation of the verbal texts follows the SFL tradition, considering a linguistic analysis within the clause. Such a design, in Ravelli's (2000) point of view, does not only permit the breaking down of texts into manageable parts. The procedure also quickens the readers' semantic understanding of the analyzed components. In that respect, Halliday's mood system from the orientation of its grammatical semiosis processes the verbal structures, generating meaning potential from the clauses as explained in the semantic slots of Texts, 1, 2, 3-10.

Technological tools of tables and graphs have aided in the calibration of transforming the components into readable figures. The tables record the recurrence of the mood systemic elements as analyzed in Tables 1, 2, 3-10, whereas the bar charts exhibit the position of each systemic component's frequency recorded in the tables. The tables and charts could assist the readers to quickly comprehend the results as illustrated later in Table 2, Figures 3 and 4 . As the ads have been presented in the discussion section, the discussion has expounded the findings by entwining the theoretical insight in Figure 2 with the analysis in Texts 1, 2, 3-10, accomplishing the image of the ads. That activity has led to the conclusion of the investigation. The symbol, $\mathbb{\circledR}$, represents a registered company; while the sign, $\varnothing$, points readers to some disjunctive portions. 


\subsection{Data Presentation}

Table 1 below exhibits the density of the ads' verbal artifacts.

TABLE 1 - Data presentation of the verbal artifacts in the ads

\begin{tabular}{|c|c|c|c|}
\hline Product & Text & Artifact Boundary & Sum \\
\hline Peak & 1 & Official milk of the Super Eagles & 1 \\
\hline Star Lite & 2 & Feel the chill here & 1 \\
\hline \multirow{11}{*}{$\begin{array}{l}\text { Union } \\
\text { Bank }\end{array}$} & $3 a$ & Don't be an Uncle Thomas & \multirow[b]{11}{*}{9} \\
\hline & $\mathrm{b}$ & Clear your doubt & \\
\hline & $\mathrm{c}$ & $* 826 \#$ & \\
\hline & $\mathrm{d}$ & Do more with $* 826 \#$ & \\
\hline & $\mathrm{e}$ & The new Union Bank USSD $* 826 \#$ is the short cut to getting things & \\
\hline & & done faster and smarter & \\
\hline & $\mathrm{f}$ & Use $* 826 \#$ to check balance, make cardless ATM withdrawals, buy & \\
\hline & & airtime and make payments & \\
\hline & $g$ & Go ahead & \\
\hline & $\mathrm{h}$ & Use $* 826 \#$ & \\
\hline & $\mathrm{i}$ & and clear your doubt & \\
\hline \multirow[t]{6}{*}{ Pepsi } & $4 \mathrm{a}$ & Wizkid & \multirow[b]{6}{*}{6} \\
\hline & $\mathrm{b}$ & Pepsi50cl back@N100 & \\
\hline & $\mathrm{c}$ & No shakin' & \\
\hline & d & Carry & \\
\hline & $\mathrm{e}$ & go! & \\
\hline & $\mathrm{f}$ & Also applies to 7Up, Mirinda, Teem & \\
\hline \multirow{7}{*}{$\begin{array}{l}\text { Exxon } \\
\text { Mobil }\end{array}$} & $5 \mathrm{a}$ & Celebrating Akwa Ibom at 30 & \multirow[b]{7}{*}{7} \\
\hline & $\mathrm{b}$ & Energy lives here & \\
\hline & $\mathrm{c}$ & The land of promise & \\
\hline & $\mathrm{d}$ & We felicitate the government and people of Akwa Ibom & \\
\hline & $\mathrm{e}$ & as the state celebrates 30 years of prosperity and growth & \\
\hline & $\mathrm{f}$ & We're proud to be part of your history & \\
\hline & g & and look forward to greater achievements for the people of Akwa Ibom & \\
\hline
\end{tabular}




\begin{tabular}{|c|c|c|c|}
\hline \multirow[t]{7}{*}{ Airtel } & $6 a$ & Dial a doctor 67777 & \multirow[b]{7}{*}{7} \\
\hline & $\mathrm{b}$ & another first from Airtel & \\
\hline & c & keep your mind at peace & \\
\hline & $\mathrm{d}$ & dial a doctor now & \\
\hline & e & dial 67777 at $\mathrm{N} 30 / \mathrm{min}$ to speak to a doctor & \\
\hline & $\mathrm{f}$ & Terms and consditions apply & \\
\hline & g & Come alive with Airtel & \\
\hline Harp & 7 & Promise of perfection best enjoyed with Harp & 1 \\
\hline \multirow[t]{4}{*}{ FCMB } & $8 \mathrm{a}$ & Wishing all Muslim faithfuls a fulfilling and rewarding celebration & \\
\hline & $\mathrm{b}$ & as you consolidate on the blessing of Ramadan & \\
\hline & c & Happy Eid-el-Fitr & \\
\hline & d & From all of us at FCMB & 4 \\
\hline \multirow[t]{3}{*}{ Guinness } & $9 \mathrm{a}$ & The beer without equal & \\
\hline & $\mathrm{b}$ & Drink responsibly & \\
\hline & c & Guinness the power of Naija & 3 \\
\hline \multirow[t]{2}{*}{ Maltina } & $10 \mathrm{a}$ & The new face of happiness & \\
\hline & $\mathrm{b}$ & sharing happinness & 2 \\
\hline
\end{tabular}

For the sake of explanatory adequacy, I have integrated the data analysis of the verbal artifacts as part of the discussions. Therefore, this study presents the advertising framework first with the analysis of the lexemic choices following each advertising plate as the second device. The application of the mood system to the verbal elements follows that reported by Halliday and Matthiessen (2004).

\section{Analysis and Discussion}

Meaning derivatives in Interpersonal Metafunction, that is, in clause as exchange, attracts the combination of mood resources exemplified in Figure 2 and the grammatical semiosis items operating in the semiotic slots as demonstrated in the analysis in Texts 1,2,3-10. It is upon that intertwining relationship that the explanations of the advertising texts (artifacts) are underpinned. Nonetheless, the arguments follow according to that reported by Bloor and Bloor (2013), Fontaine (2013), and Halliday and Matthiessen (2014). 


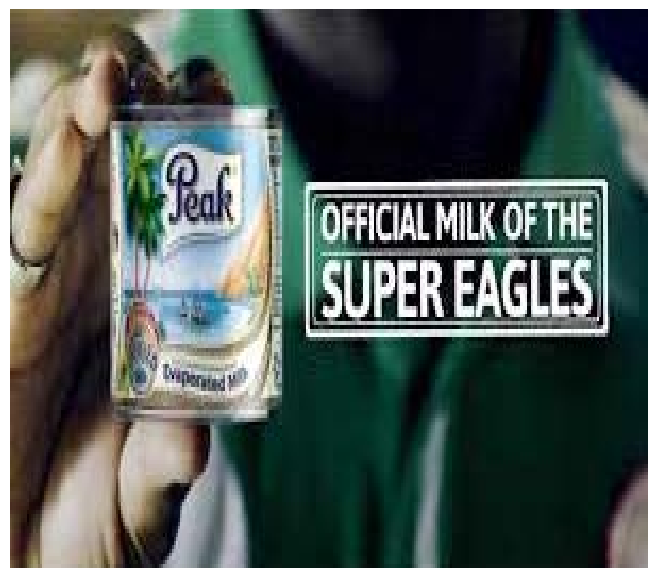

Ad 1

\begin{tabular}{|l|l|l|l|}
\hline Peak & $\varnothing$ & official milk & of the Super Eagles \\
\hline Subject & & Complement & Adjunct \\
\hline Mood & Residue \\
\hline
\end{tabular}

Text 1

The Peak ${ }^{\circledR}$ milk ad in Text 1 deploys only one clause. That is, Peak official milk of the Super Eagles ${ }^{2}$. The first observation in the structure is that some linguistic elements have been deleted. Peak is the Subject without the Finite in the domain of Mood. The Residue includes the Complement and Adjunct. The deleted items are between the Subject and the Complement, which could be suggested as is the: where is is the Finite and the is the definite article of the official milk serving a purpose of certainty. The image, seemingly appearing as a non-verbal mode, takes the place of the Subject, eliminating unnecessary lexemes, bringing together the desired ostensible stimulus. Thus, the full clause might appear as Peak [is the] official milk of the Super Eagles. In that sense, the role initiator of the commodity gives information to the audience which is the statement, in Halliday and Matthiessen's (2014) terminology. The clause is an open statement that does not require a response from the audience. The point is that the addresser admits a truth. The truth: Peak, not any other brand, is the officially assigned milk for the Super Eagles' consumption. Such association could attract the fans to buy the Peak milk.

${ }^{2}$ Super Eagles: The Nigerian national football team 
Drinking Peak, one could argue, is not under obligation. The attestation, in the perspective of the advertiser, is for the sake of promotion. The mode, green, represents the Nigerian national color. The association of Peak with the Super Eagles with green color, to reiterate, is a means of informing the public that the Nigerian soccer players, of this professional level, consume Peak milk. As a result of the approval, the milk is placed at the echelon of a high quality product that takes a great care of the players' health. Such a claim rests on the fact that people inclined with sports are healthy people (BAILEY, COPE; PARNELL, 2015). The marketing logic is that Peak contributes to the wellness of the Super Eagles (players) hence, the consumption of Peak provides good health for the people. The Super Eagles' consumption of the milk, as claimed, is a strategy to sensitize the entourage, fans and the entire Nigerian public to the consumption of Peak milk. Therefore, the focus is not only on the soccer team of miniaturized membership; the goal has shifted to the entire public domain that love and watch the Super Eagles. That seems the reason for using a hand of an individual as a mode to present the milk to the target audience. The Peak advertiser anchors the quality of the milk on a social event (REEVES, 1970; WANG, 2008).

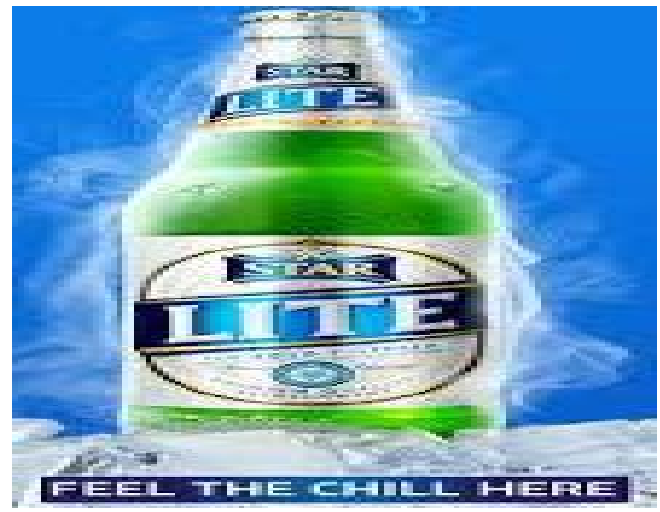

Ad 2

\begin{tabular}{|l|l|l|}
\hline Feel & the chill & here \\
\hline Predicator & Complement & Adjunct \\
\hline Residue & \multicolumn{3}{|l}{} \\
\hline
\end{tabular}

Text 2 
The clause in Text 2 is just one. Start Lite ${ }^{\circledR}$ uses Feel the chill here as the artifact of passion-cum-compassion. The clause has only the Residue of the Predicator - Feel, the Complement - the chill, and the Adjunct - bere. The advertising practitioner initiates this commodity to demand goods- $\&$ services from the audience. Feel the chill here is a proposal that the initiator expects somewhat a positive response from readers. As the advertiser commands readers to Feel the chill here readers might refuse to do as directed, positioning the command as being discretionary. Although the advertising artifact appears as one-way communication (AWONUSI, 2007), one could argue that it is far from that. This is on the ground that the advertising text indirectly involves at least two interactants - the advertiser and the target audience. The advertiser employs a modal text to motivate the audience to consumption whereas the response of the target audience is not verbal. The response is reckonable based on the patronage of the advertised Star Lite. Thus, the quantity of the advertised product sold invariably delineates the positive response of the target audience. This is a business interaction achieved through communicating the individuals. As a matter of arousing the interest of consumers, Star Lite adopts phonological devices of / i:l/ for Feel and / i:l/ for chill, creating an assonance relationship with readers (MYERS, 1994; ADETUGBO, 1997; MALMKJEAR, 2004; CLARKE; YALLOP, 1995).

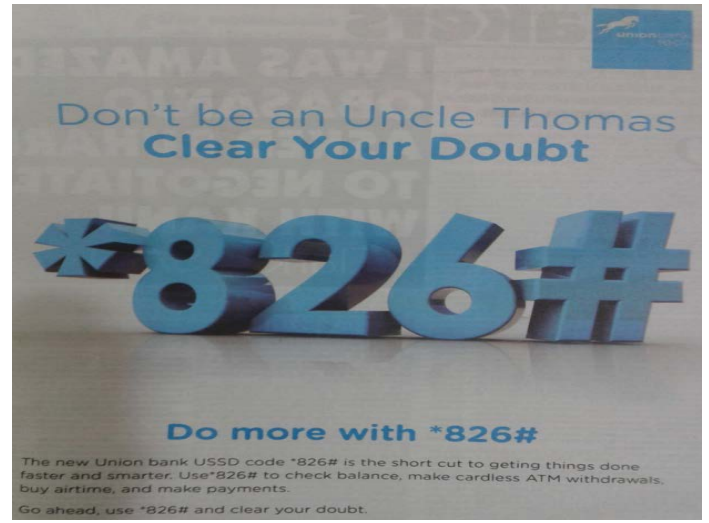

Ad 3 


\begin{tabular}{|c|c|c|c|}
\hline Subject & Mod Adj & Predicator & Adjunct \\
\hline Mood & & \multicolumn{2}{|l|}{ Residue } \\
\hline
\end{tabular}

\begin{tabular}{|c|c|c|}
\hline Wishing & the Muslim faithfuls & a fulfilling and rewarding celebration \\
\hline Predicator & Complement & Complement \\
\hline \multicolumn{3}{|l|}{ Residue } \\
\hline
\end{tabular}

b \begin{tabular}{|l|l|l|l|}
\hline as & you & consolidate & on the blessing of Ramadan \\
\hline
\end{tabular} \begin{tabular}{l|l|l|l|} 
Subject & Present:Fin & consolidate:Pred & Adjunct \\
\hline
\end{tabular} \begin{tabular}{|l|l|}
\hline Mood & Residue \\
\hline
\end{tabular}

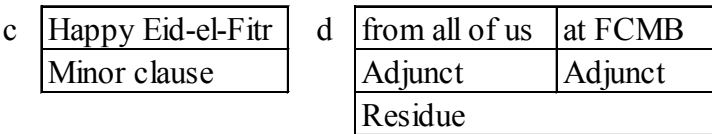

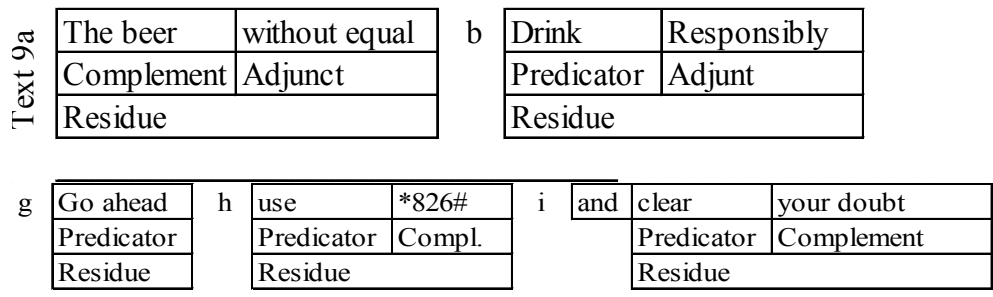

Text 3

There are nine clauses in the Union Bank $k^{\circledR}$ ad of Text 3 , in which two of the clauses are declaratives and seven are imperatives. Beginning from the declaratives, $* 826 \#$ is a fragmented statement; and The new Union Bank USSD code *826\# is the short cut to getting things done faster and smarter is an open statement. The commodity of exchange here is in the form of a statement. In that sense, the technical term is that of giving information to the addressee. The clauses are constitutive because they are propositions (THOMPSON, 2014). The advertising professional employs both expressions to acknowledge the efficacy of the digital mode, *826\#. In Text 3 , the study positions $* 826 \#$ as the Complement because it is a member of a chopped up clause. The structure could be suggested as Here is to produce a complete statement of [Here is] *826\#. The verbal mode becomes necessary because the ad lacks any pictorial mode to support the $* 826 \#$ effects. The deployment of the declarative clause in its fullness becomes crucial for the core of the message, which in the communicator's approach, is the 
code, *826\#. On the one hand, the boldness of the code and the center stage that the symbol occupies attest to that argument. On the other hand, the ad supports that comment by ensuring that $* 826 \#$ recurs five consecutive times in the entire frame.

Text $3 \mathrm{e}$ reveals the ownership, function, and characteristics of the code through grammatical resources. The new Union Bank USSD code *826\# as the Subject displays Union Bank as the sponsor of the ad and $* 826 \#$ as the operational code for the target audience who use Dollars in their transactions. The Finite, is, creates an Ideational relationship between the Subject and the Complement (BLOOR; BLOOR, 2013). The reversibility of the Subject and the Complement demonstrates that the Finite, $i$, in its present status functions as a Relational identifying process. The Complement, the short cut to getting things done faster and smarter, elicits the audience about the features of the code. The Adjunct in 3f, to check balance, make cardless $A_{T M}^{3}$ withdrawals, buy airtime and makepayments, does not only reiterate the attributes of $* 826 \#$, but the structure also reinforces the code as an effective and efficient electronic facility. The code, *826\#, from the advertiser's point of view, is new because the digital mode refers to the nearest future and is user friendly, characterized by speed and intelligence. That quality defines $* 826 \#$ as a clever, compatible, and sensible tool and that consumers will definitely appreciate its functional competence.

Texts $3 \mathrm{a}, 3 \mathrm{~b}, 3 \mathrm{~d}, 3 \mathrm{f}, 3 \mathrm{~g}$, $3 \mathrm{~h}$ and $3 \mathrm{i}$, as they are imperative clauses, the matter of the Subject and the Finite is actually ruled out; thus, the clauses contain Residue(s). Deriving meaning potential from the role initiation of the commodity's insight, the exchange in all of the six clauses is that the initiator (advertiser) demands goods- $\&$-services from the audience (consumer). Thus, the semantic implication in all the exchange(s) is ancillary. The basis is that the advertising expert makes only proposals to consumers of the message. Don't be Uncle Thomas, in Text 3a, has the Predicator and the Complement as grammatical transpositions. The Predicator, Don't be, expresses negation. The negative polarity is to instill confidence in readers and to dispel distrust. The assurance of the effectiveness of $* 826 \#$ has a link with the Complement, Uncle Thomas. In this vein, the advertiser has gone religious. The individual narrator has interconnected the characteristic of Thomas, a disciple of Jesus Christ, to construct the behaviors of some readers. The biblical Thomas is popularly called the doubting Thomas, so

${ }^{3}$ ATM: Automatic Teller Machine 
the advertiser adopts that concept to characterize readers. It is on that basis, however, that the initiator of the exchange advises that: Don't be Uncle Thomas. In a simple term, the audience must believe the digital mode in order to $D o$ more with *826\#. Clear your doubt, repetitively functioning as clauses of the communication, depicts the concept of being Uncle Thomas more often than not. The Adjunct, with*826\#, in $3 \mathrm{~d}$ points readers to the code as a means of accomplishing their desired international banking transactions.

Apart from the Predicator, Go ahead, which creates enthusiasm for readers, the entire advertising communication is surrounded by repetitions (PACKARD, 2007). As stated earlier, *826\# operates five times in the following sequences: as the Subject, one time (in Text 3e); as the Complement, three times (in Texts $3 \mathrm{c}, 3 \mathrm{f}$ and $3 \mathrm{~g}$ ); and as the Adjunct, one time (Text 3d). The primary modal process, do, functions two times in both negative and positive forms (as in Texts $3 \mathrm{a}$ and $3 \mathrm{~d}$ ). The Predicator, use, also functions two times in Texts $3 \mathrm{f}$ and $3 \mathrm{~h}$ respectively. The concept of suspicion illuminated as Uncle Thomas and doubt enjoys repetition in Texts $3 \mathrm{a}, 3 \mathrm{~b}$, and 3i. One also observes, the advertiser's emphasis on the features of the mode, ${ }^{*} 826 \#$, as in the Complement of Text $3 \mathrm{e}$ and the Adjunct of Text 3 f. Given that impressive prominence, the advertising creator intends to establish the concept of $* 826 \#$ as one of the memorabilia (i.e. things worthy of remembrance) in the financial sector of the Nigerian economy. Besides the Jaguar-like made in the emblem of Union Bank, all the other modes are verbal elements.

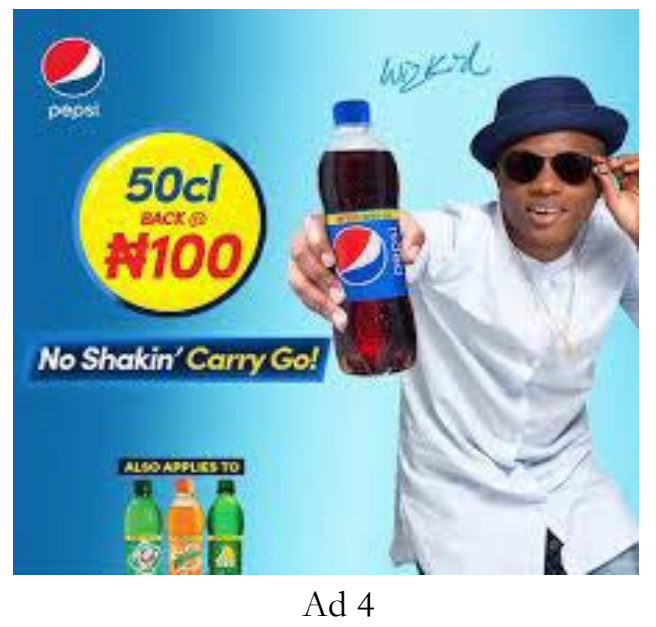




\begin{tabular}{|c|c|c|c|c|c|c|c|}
\hline Wizkid & \multirow[t]{3}{*}{$b$} & Pepsi 50c1 & \multirow{2}{*}{18} & \multicolumn{2}{|l|}{ back } & a)N100 & \multirow{2}{*}{\begin{tabular}{|l|} 
No shakin' \\
Complement \\
\end{tabular}} \\
\hline Complement & & Subject & & \multicolumn{2}{|c|}{ Complement } & Adjunct & \\
\hline Residue & & Mood & & \multicolumn{3}{|c|}{ Residue } & Residue \\
\hline Carry & \multirow[t]{3}{*}{ e } & go! & \multirow[t]{4}{*}{$\mathrm{f}$} & \multirow[t]{4}{*}{ Also } & \multicolumn{2}{|l|}{ applies } & \multirow{2}{*}{$\begin{array}{l}\text { to } 7 \mathrm{Up}, \text { Mirinda } \\
\text { Teem }\end{array}$} \\
\hline Predicator & & \multirow{2}{*}{\begin{tabular}{|l} 
Predicator \\
Residue
\end{tabular}} & & & \multirow{2}{*}{$\begin{array}{l}\text { Present } \\
\text { Finite }\end{array}$} & \multirow{2}{*}{$\begin{array}{l}\text { apply: } \\
\text { Predicator }\end{array}$} & \\
\hline Residue & & & & & & & Adjunct \\
\hline & & & & & Mood & Residue & \\
\hline
\end{tabular}

Text 4

The advertising communication in Text 4 contains six clauses. As a common factor, all the clauses are punctuated in one form or another. Clauses $4 \mathrm{a}, 4 \mathrm{~b}, 4 \mathrm{c}$, and $4 \mathrm{f}$ are declaratives, while clauses $4 \mathrm{~d}$ and $4 \mathrm{e}$ are imperatives. In $4 \mathrm{a}$, the advertiser only reveals the verbal mode, $W$ iqkid, as a name of a celebrity. Wiqkid is a prime mover in the Nigerian music industry among the youth (THE SUN, 2018). The grammatical semiosis indicates $W$ iqkid as a Complement with other elements being punctuated. The configuration of This is appears as the Subject-cum-Finite deleted from the clause. With that, [This is] Wizkid could be the full declarative clause. Given that construction, the role initiation of commodity accounts for the speaker's interaction as giving information to the audience whereby

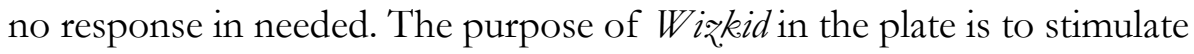
readers to the real message of the ad. Most times, advertisers (a handful of them) present renowned images of artists to persuade the audience to consumption (MYERS, 1986; MASSARIS, 1994, 1997; NIXON, 1996). The disjunctive grammatical organization of Text $4 \mathrm{~b}$ is different from Text $4 \mathrm{a}$. In this sense, the clause has Pepsi $i^{\circledR}$ 50 clas the Subject, back, as the Complement and $¥ 100^{4}$ as the Adjunct. There is no Finite at all. The Finite, to the author's mind, is is. The clause could thus read:Pepsi50cl [is]back@100. With that, giving information is also the role of the speaker in the communication exchange. At this juncture, one might stress that the communicator exhibits Pepsi, the advertised product, in both verbal and non-verbal modes in order to create the enabling environment for its acceptance.

A similar exchange is applicable to the clauses in Texts $4 \mathrm{c}$ and $4 \mathrm{f}$. The Complement, No shakin', as deployed in Text 4c illustrates a linguistic

${ }^{4}$ \#: The symbol of the Nigerian currency 
expression contracted from both ends. The modules, There is, Subject and Finite, indicating the existence of an event, seem to be the punctuated devices, from the left-hand side. The grapheme $g$ is also cut off from shaking, from the right-hand side, to produce shakin'. This textual communicative behavior shows that advertisers fabricate lexemic variants to establish a connection with the audience to suit an intended purpose (MYERS, 1994). One can also have a similar experience in Text $4 \mathrm{f}$ where This term as the Subject does not operate in the clause. By suggestion, the clause is [This term] also applies to $7 \mathrm{Up}^{\circledR}$, Mirinda ${ }^{\circledR}$ and Teem ${ }^{\circledR}$. Wasting of words is aberrant in advertising. That means, advertisers avoid verbosity by all means in communicating to viewers who, perhaps, have little or no time to read advertising nuances (COOK, 2001). Although Text 4d, Carry, and Text $4 \mathrm{e}$, go!, share a basic foundation with other linguistic elements in terms of structural disjunctions. The processes are imperatives that serve as platforms for the advertiser to demand goods- $\&$-services to perform an ancillary function. Had the communicator not fragmented the clauses, the complex clause might have appeared as Carry [Pepsi and] go [your way!]. Pepsi as well as your way are the probable deleted linguistic items. Nevertheless, the image as a whole provides information that connects the propagated verbal facilities, yielding meaning potential. This is because the Wirkid's pictorial mode is an object of love, trust, and confidence among the Nigerian youths. The publicist entwines such characteristics with the verbal modes as the point of interaction (WILLIAMSON, 1978).

Contextually, it is worth mentioning that the Complement, No shakin' and the Predicators Carry go! operate as Pidgin and slang in the Pepsi advertising frame (DALAMU, 2017b). No shakin' is an expression ascertaining self-assurance of the quality of Pepsi for the audience. Carry go! dispels fear from consumers in terms of the quality and the quantity of the product. Hence, No shakin' and Carry go!, from my vantage point, are pidginized proposals indicating youthful exuberance in the form of slang. Nevertheless, the genesis of the ad is that the manufacturer of Pepsi, 7Up, Mirinda and Teem (7Up Industries ${ }^{\mathbb{R}}$ ), some time ago, increased the prices of the products from $¥ 100$ to $\$ 120$. Perhaps, due to drop in sales, the management moved into the market situation to influence the consumer behavior toward the demand. Given the new decision, the ad in Text 4 responded to inform the target audience of the new price development as a means of gaining the appropriate market share. 


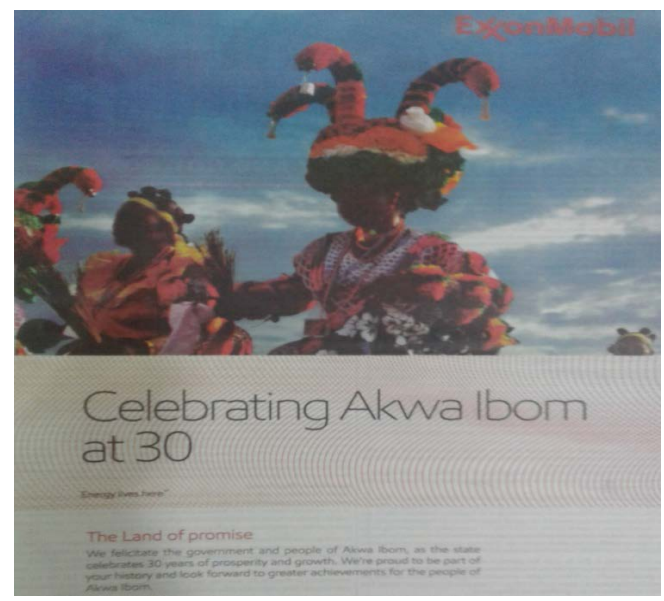

Ad 5

a

\begin{tabular}{|l|l|l|}
\hline Celebrating & Akwa Ibom & at 30 \\
\hline Predicator & Complement & Adjunct \\
\hline Residue & \\
\hline
\end{tabular}

\begin{tabular}{|l|l|l|l|}
\hline Energy & lives & here \\
\hline Subject & Present:Fin & live:Pred & Adjunct \\
\hline Mood & Residue \\
\hline
\end{tabular}

$\mathrm{c}$

\begin{tabular}{|c|c|c|c|c|c|}
\hline The land of promise & \multirow[t]{3}{*}{$\mathrm{We}$} & \multicolumn{2}{|l|}{ felicitate } & \multirow{2}{*}{$\begin{array}{l}\text { the government } \\
\text { and people }\end{array}$} & \multirow{2}{*}{$\begin{array}{l}\text { of Akwa } \\
\text { Ibom } \\
\end{array}$} \\
\hline Complement & & Present: & felicitate: & & \\
\hline \multirow[t]{2}{*}{ Residue } & & Finite & Pred & Complement & Adjunct \\
\hline & \multicolumn{2}{|l|}{ Mood } & \multicolumn{3}{|l|}{ Residue } \\
\hline
\end{tabular}

e

\begin{tabular}{|c|c|c|c|c|}
\hline as & the state celebrates & & 30 years & of prosperity and growth \\
\hline & Subject Prest: Fin & celebrate: Pred & Complement & Adjunct \\
\hline & Mood & Residue & & \\
\hline
\end{tabular}

\begin{tabular}{|l|l|l|l|l|}
\hline We & 're & proud & to be part & of your history \\
\hline Subject & Finite & Complement & Adjunct & Adjunct \\
\hline Mood & \multicolumn{4}{|c|}{ Residue } \\
\hline
\end{tabular}

g

\begin{tabular}{|l|l|l|l|l|}
\hline and & look forward to & greater & for the people of \\
\hline \multirow{2}{*}{$\begin{array}{l}\text { Present: } \\
\text { Finite }\end{array}$} & look forward to: & Predicator & achievements & Akwa Ibom \\
\cline { 2 - 4 } & Mood & Residue & Adjunct & Adjunct \\
\hline
\end{tabular}

\section{Text 5}

The ExxonMobil ${ }^{\circledR}$ ad in Text 5 is not about selling a product, but the communication is rather about the exaltation of the years of existence of 
Akwa Ibom. ${ }^{5}$ The ad acknowledges the ritual gratitude through the clustering verbal modes, Celebrating Akwa Ibom at 30 in Text 5a. In addition, six other clauses are used as propositions to commemorate the $30^{\text {th }}$ anniversary of the creation of the state. In that regard, ExxonMobil, the advertiser, initiates the role of commodity for exchange by giving information to the people in which no response is required. Structurally, three clauses function within the influence of disjunctive vectors. These norms are operational in Text $5 \mathrm{a}$ as Celebrating Akwa Ibom at 30 instead of [We are] celebrating Akwa Ibom at 30; in 5c as The land of promise instead of [Akwa Ibom is] the land of promise; and in $5 \mathrm{~g}$ as look forward to greater achievements for the people of Akwa Ibom instead of [We] look. forward to greater achievements for the people of Akwa Ibom. However, the pictorial modes of people appearing in Akwa Ibom's cultural heritage, one might suggest, functions as a replacement for the punctuated verbal components. Consequently, the publicist employs the pictorial modes to construct the verbal modes, creating the necessary information for the audience.

In Text $5 \mathrm{a}$ and $5 \mathrm{c}$, the ad eliminates the Subjects (We, Akwa Ibom) and the Finites (are, is) respectively in the arrangement, while only Subject (We) suffers the fate of omission in the structure. The influx of fragmentations re-establishes the concept as an inevitable conduct of advertising phenomena (VESTERGAARD; SCHRODER, 1985). In addition, by the appearance of the structure, the Given construct is likely to be phoric, referring to an element that is already present in the communicative context. One way of achieving phoricity is through ellipsis. In this case, the communicator expects readers to supply $W e$ as the Subject in order to interpret the clause as an offer. This is made possible because readers operate on the basic principle of all linguistic interaction. That is, the principle that what the speaker says makes sense in its current context (HALLIDAY; MATTHIESSEN, 2014, p. 116, 195). The analyst could connect the social tune of the ExxonMobilad to four input variables. The gradable parameters are association, evaluation, exaltation, and future benefits. Text 5a (Celebrating Akwa Ibom), Text 5d (we felicitate the government and people of Akwa Ibom), and Text $5 \mathrm{f}$ (We're proud to be part of your history) are associative concerns. The verbal artifacts link ExxonMobil to the government and people of Akwa Ibom. Structures such as [We are] celebrating; We felicitate, and We're proud specify the required social relations. The clauses illustrate that ExxonMobilis not only producing in the state, it is also part of

${ }^{5}$ Akwa Ibom: An oil producing state of Nigeria located in the South-South geo-political zone 
the solemnization. This is a path of honor, in my perspective, for ExxonMobil to reach the people. Those familiarization claims classify the company as responsible to the people. These clichés in the form of social marketing (BRIERLEY, 1995) could augment peaceful operations for ExxonMobil in the Akwa Ibom state. The communication recognizes the social acceptance of the oil and gas company by the government and people of the state.

ExxonMobil also attempts to appraise and exalt the state by using propositions such as Energy lives here and [Akwa Ibom is] the land of promise. The Subject, Energy, operates as metonymy and in the form of an animated being (ALOUSQUE, 2015; PÉREZ-SOBRINO, 2016). In a sense, Energy represents petroleum resources, while the "fused" Finite-Predicator, lives, extols Energy as an animate entity. The land of promise, the Complement, is an affirmation of great resourceful potential in the state. It is on that basis that the declarative, $[\mathrm{We}]$ look forward to greater achievements for the people of Akwa Ibom, becomes pertinent as an indicator of future gains. That assertion is to notify the target audience that ExxonMobil has come to stay in Akwa Ibom, and it is not in a hurry to go somewhere else except for a purpose of expansion. The writer might connect the ExxonMobil's canvassing partnership with the people to mean "Stronger Together", which is an aphorism (HUI, 2019) of the Hillary Clinton and Kaine (2016) electoral campaign book of the 2016 United States Presidential Election.

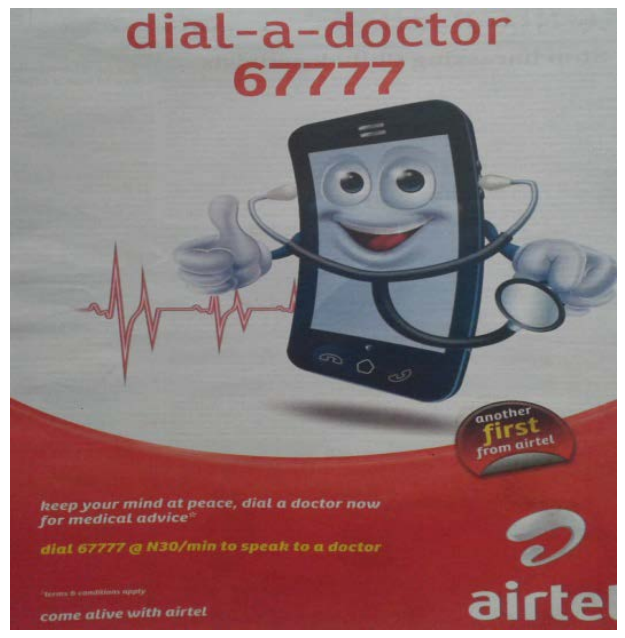

Ad 6 


\begin{tabular}{|l|l|l|}
\hline Dail & a doctor & $\varnothing 67777$ \\
\hline Predicator & Complement & Adjunct \\
\hline Residue & \multicolumn{2}{|l}{} \\
\hline
\end{tabular}

\begin{tabular}{|l|l|}
\hline another first & from airtel \\
\hline Complement & Adjunct \\
\hline Redue \\
\hline
\end{tabular}

\begin{tabular}{l|l|l|l|}
\hline keep & your mind & at peace \\
\hline Predicator & Complement & Adjunct \\
\hline Residue \\
\hline
\end{tabular}

\begin{tabular}{|l|l|l|l|}
\hline dial & $\begin{array}{l}\text { a } \\
\text { doctor }\end{array}$ & now & $\begin{array}{l}\text { for a medi- } \\
\text { cal service }\end{array}$ \\
\hline Predicator & Compl. & Adjunct & Adjunct \\
\hline Residue
\end{tabular}

\begin{tabular}{|l|l|l|l|l|}
\hline e dial & 67777 & at N30/min & to speak & to a doctor \\
\hline Predicator & Complement & Adjunct & Adjunct & Adjunct \\
\hline Residue &
\end{tabular}

\begin{tabular}{|l|l|l|}
\hline Terms and conditions & \multicolumn{3}{|l|}{ apply } \\
\cline { 2 - 3 } Subject & Present:Fin & apply:Pred \\
\hline Mood & Residue \\
\hline
\end{tabular}

g \begin{tabular}{|l|l|l|}
\hline Come & alive & with airtel \\
\hline Pred & Compl. & Adjunct \\
\hline
\end{tabular}

\section{Text 6}

There are seven clauses in the Airte $^{\mathbb{B}}$ ad of Text 6 . Two of the clauses are declaratives while five of them are imperatives. Even at that, apart from clause 6a, which expresses the Subject, Terms and conditions, and the Finite, apply, all other grammatical semiosis operands in the entire clauses are Residues that function as Predicators, Complements, and Adjuncts. Moreover, the communication signifies the role initiation of commodity in both Texts $6 \mathrm{a}$ and of as giving information to the target audience without expecting responses. This is because the clauses are propositions that perform constitutive functions. Nonetheless, clauses $6 \mathrm{a}, 6 \mathrm{c}, 6 \mathrm{~d}, 6 \mathrm{e}$, and $6 \mathrm{~g}$ perform ancillary functions, since the messages are proposals that require certain actions from individuals. The "interact" in the domain of these imperative clauses operates as demanding goods- $\&$-services from the target audience.

There are omissions in clauses $6 \mathrm{~b}$ and $6 \mathrm{f}$. The hypothesized communicative facilities are This is to produce [This is] another first from Airtel; and to this promotion to yield Terms and conditions apply [to this promotion]. Clause of would not have been accounted for as being punctuated but the verbal group, apply, is a transitive process that deserves an Adjunct. The Complement, another first, demonstrates a pioneering effort of the Airtel telecommunications firm in the neighborhood of medication. Airtel, the company, initiates the procedure thus: Dial a doctor through 67777. 
Observations show that the lexicon, dial, recurs three times in clauses $6 \mathrm{a}, 6 \mathrm{~d}$, and $6 \mathrm{e}$. The repetition of dial is impressionistic as an indentation encouraging readers to take a particular action. Although 67777 is a number that links a subscriber to a doctor, Airtel highlights that the call is not free of charge. As indicated in the Adjunct of Text 6e, dialing a doctor for medication, as a persuasive explication, costs N30/min. This is a pointer that Airtel sets out the package to generate some funds to make a handsome profit.

Furthermore, Text 6c, Keep your mind at peace, and Text 6g, Come alive with Airtel, urge readers to maintain a very strong relationship with the firm. Health matters more than anything else seem to be an important factor in human lives, which is a general conception (WHO, 2011). The provision and advocacy from Airtel could be a welcoming idea to subscribers because the number, 67777 , creates an opportunity for readers to get through to a "ready-made" doctorin no time. Keep your mind at peace guarantees subscribers of comfortably receiving medical attentions through Airtel. In retrospect, many readers might love to become consumers of Airtelservices. From that opinion the Airteladvertiser conveys a stimulating message of Come alive with Airtel to viewers. Such a proposal has the ability to arouse the interest of readers to become loyal to Airtel. Nonetheless, the structure, Come alive with Airtel, produces ambiguity, relating to the audience in uncertain and unclear manners (NORVIG, nd; LAGERWERF, 2002;). The imperative construct seems confusing. This is because one might generate some questions, among others, from the command (HAN; HONG-LIM, 2015). Does the advertiser mean that anyone who uses Airtel will be raised from the sick bed to becoming a healthy individual? Or that Airtel subscribers will be lively while interacting with someone? Or that people who use Airtel are always active in their activities? Or that patronizing Airtel will make users energetic and busy?

There are two significant intersectional modal devices in Ad 6. These are: a doctor (verbal mode); and a meme appearing as a doctor (non-verbal mode). One might pinpoint that the meme is a combination of a handset, a stethoscope, and an iconic human image. The advertiser employs the verbal and non-verbal modal texts to facilitate and promote the availability of medical care for Airtel subscribers. 


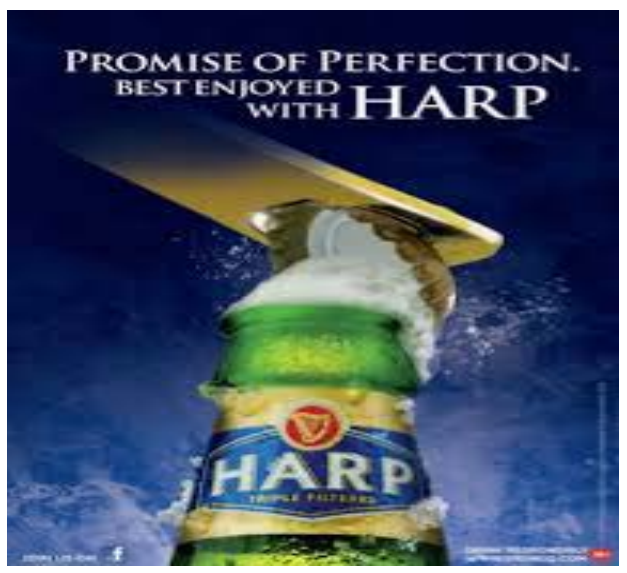

Ad 7

\begin{tabular}{|l|l|l|l|l|}
\hline Promise of perfection & & best & enjoyed & with Harp \\
\hline Subject & & Mod Adj & Predicator & Adjunct \\
\hline Mood & Residue \\
\hline
\end{tabular}

\section{Text 7}

The communicative verbal artifact in Text 7 appears in two shapes. The statuses seem as two clauses most especially with the introduction of a period (full stop) at the end of the first disjunctive construct. However, the Harp $^{\circledR}$ ad contains only one clause shared into two different communicative units. Promise of perfection, a nominal group with a period, is an orthographic sentence because of the sign of full stop at its end (COOK, 2001). The second verbal artifact, best enjoyed with Harp, also functions as a fragmentation device. Those linguistic matrices are punctuated from a simple clause so that the element could be divided into two separate pieces of information. On the one hand, from a grammatical perspective, one might suggest the clause to be $[A]$ promise of perfection [is] best enjoyed with Harp. An indefinite determiner, $a$, as well as the Finite, is, have been abolished from the advertising communicative purpose, hanging on the notion of textual economy (HERMERÉN, 1999). On the other hand, the combination of modes (the neck of Harp bottle, the foaming quality, and the Harp label), representing Harp might function as the interactive resources replacing the verbally punctuated portions. Thus, I might reshape the earlier clauses as [Harp has a] promise of perfection. And that the non-verbal foaming appearance 
(initiated with the assistance of the opener) signifies the content of Harp for a purpose of enticing and creating a tasty urge for viewers.

The clause, as exchange, operates as a way to provide information to the public. In this respect, there is no response expected from consumers of the message. As it were, $[A]$ promise of perfection [is] best enjoyed with Harp is a proposition, as illustrated in Figure 2, performing a constitutive function. The Subject, Promise of perfection, (if there is anything like that) refers to a kind of vow that someone has made devoid of flaws. The advertising professional places some values on such moral excellence, binding the individuals involved in the impeccable oath in order to promote the consumption of Harp. The lager beer, in the purview of the advertising expert, engages individuals in an ideal setting to achieve desired results. The Modal Adjunct, best, evokes a sort of infallibility on Harp as an object that conjugates partners in socio-cultural transactions.

Although the advertiser has a reason for promoting the patronage of the product by deploying such a lexeme for conviction, one could argue with an inquiry that: How can a situation or the consumption of Harp become immaculate? Such a juxtaposition only edifies the product as seemingly the best among the rest in the market. However, it is a great task for the beer to attain the proposed position of flawlessness, perhaps, in the sights of analysts and consumers. Gaining attention and motivating the larger audience to buy a product, as Rossiter and Percy (1987) have commented, are the burdens of advertising. Thus, it is unsurprising for readers and analysts to observe claims, nauseating images, and unusual textual properties in advertising frames as swaying instruments. 


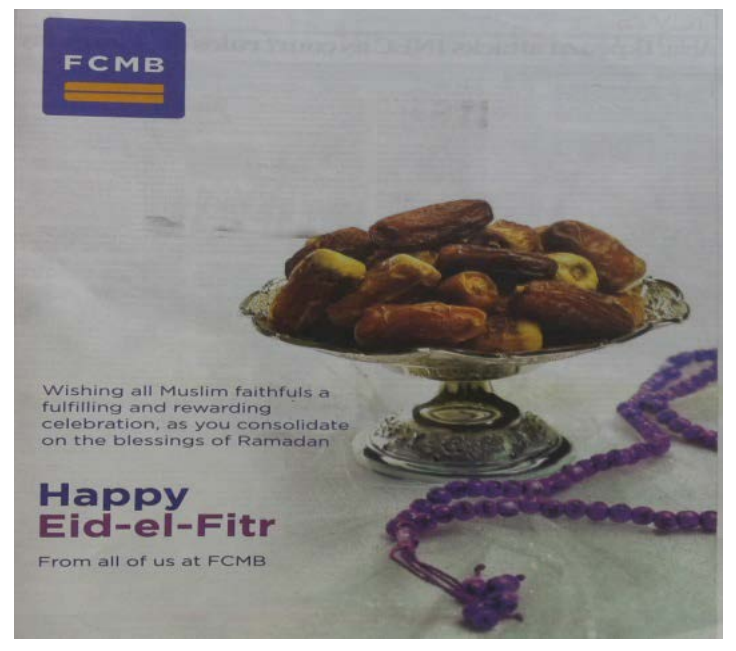

Ad 8

\begin{tabular}{|l|l|l|l|}
\hline Wishing & all Muslim faithfuls & a fulfilling and rewarding celebration \\
\hline & Predicator & Complement & Complement \\
\hline Residue & \multicolumn{2}{|l}{} \\
\hline
\end{tabular}

$\mathrm{b}$

\begin{tabular}{|l|l|l|l|l|}
\hline as & you & consolidate & on the blessing of Ramadan \\
\hline & Subject & Present:Fin & consolidate:Pred & Adjunct \\
\hline Mood & Residue & \\
\cline { 2 - 4 }
\end{tabular}

c \begin{tabular}{|l|}
\hline Happy Eid-el-Fitr \\
\hline Minor clause \\
\hline
\end{tabular}

\begin{tabular}{|l|l|}
\hline from all of us & at FCMB \\
\hline Adjunct & Adjunct \\
\hline Residue \\
\hline
\end{tabular}

Text 8

$F C M B^{\circledR}$ deploys the verbal artifact in Text 8 as a congratulatory message to Muslim brothers and sisters. Notably, the communication gives information as an open statement to readers without any expectation of response. By that, the texts operate as a proposition performing constitutive functions. Among the four clauses in the ad, two of the expressions are fragmented, while the remaining clauses are not. The clauses with structural omissions are: Wishing all Muslim faithfuls a fulfilling and rewarding celebration and From all of us at FCMB. The advertising expert takes away We are (Subject 
+ Finite) from Text 8a and This message is (Subject + Finite) from Text $8 \mathrm{~d}$ respectively. Given the suggestive elements, the constructs in their fullfledged forms ought to be: [We are] wishing all Muslim faithful a fulfilling and rewarding celebration and [This message is] from all of us at FCMB.

The circumstantial Adjunct, From all of us at FCMB, performs a locative responsibility, specifying the source of the congratulatory message and at the same time establishing the sponsor of the ad. Actually, the ad seems not to be selling anything to the audience, nevertheless, the ad has a marketing undertone. That is the motive for allocating the logo of FCMB at the top corner of the ad as well as the underpinning of Text $8 \mathrm{~d}$ with the Adjunct, at FCMB. One might further argue that the FCMB mode on top seemingly operates as a delegate of the missing element of Text $8 \mathrm{a}$. As an alternative to the earlier suggested clauses, the FCMB logo links Text 8a to make the two modes a complete declarative clause. These appearances are deliberate so that the target audience (Muslims and non-Muslims) can patronize FCMB even after the Eid-el-Fitr celebration. Besides the embossment of FCMB on the artifact, Texts $8 \mathrm{~b}$ and $8 \mathrm{c}$ exhibit the primary mission of the communication thus: as you consolidate on the blessing of Ramadan; and Happy Eid-el-Fitr. The former is a declarative clause, while the later is a minor clause. Happy Eid-el-Fitr belongs to "sets" construct in English, which need not undergo further analysis beyond being a minor clause for a greeting purpose.

Text 8b operates in Mood and Residue constituents. It is salient to observe that the verbal group, consolidate, functions as the Finite (present) of the Mood at the same time the Predicator (consolidate) of the Residue. SFL elucidates such linguistic content as being "fused." To me, this is one of the beauties of Halliday's mood semantic resources appreciating the "goingson" as Predicator and not as Predicate (HALLIDAY; MATTHIESSEN, 2004). The social context of the ad focuses on the Muslims who have just concluded the 30-day fasting and enjoying the Ramadan. The Complement, all Muslim faithfuls and the Adjunct, on the blessing of Ramadan, support that argument. 


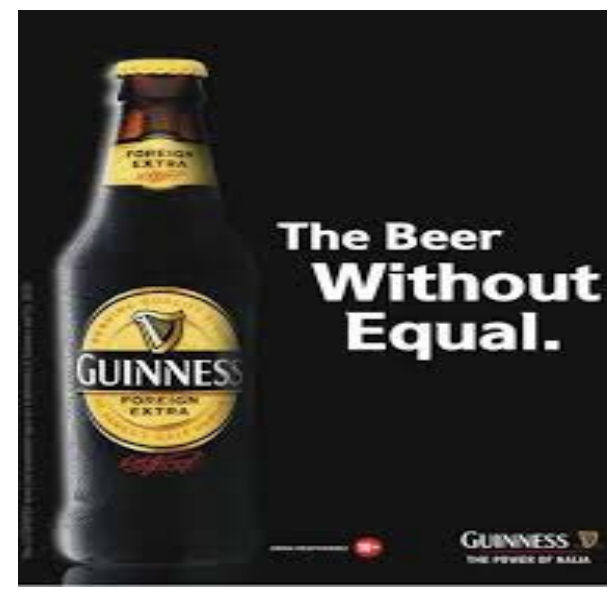

Ad 9

a

\begin{tabular}{|l|l|}
\hline The beer & without equal \\
\hline Complement & Adjunct \\
\hline Residue \\
\hline
\end{tabular}

$\mathrm{b}$

\begin{tabular}{|l|l|}
\hline Drink & Responsibly \\
\hline Predicator & Adjunt \\
\hline Residue \\
\hline
\end{tabular}

$\mathrm{c}$

\begin{tabular}{|l|l|l|l|}
\hline Guinness & $\varnothing$ & the power & of Naija \\
\hline Subject & & Complement & Adjunct \\
\hline Mood & & Residue & \\
\hline
\end{tabular}

Text 9

There are three clauses in the Guinness $^{\circledR}$ ad of Text 9. Text 9a, The beer without equal, is declarative; Text 9b, Drink responsibly is imperative; and Text 9c, Guinness power of Naija ${ }^{6}$ is also declarative. These manifestations characterize the initiating role of commodities of the clauses in the following sequences: (i) Texts 9a and 9c are under the guise of the addresser giving information to the addressee; and (ii) Text $9 \mathrm{~b}$ represents the addresser's action of demanding goods- $\&$-services from the addressee. In this respect, the former does not need a response from the target audience of the ad, whereas the later requires a response from the consumer. First, Texts 9a and 9c are open statements providing pieces of information to viewers. Second, Text 9b commands readers to take up a particular responsibility.

${ }^{6}$ Naija: Slang, operating as a short form of Nigeria 
Thus, one could argue that Drink responsibly is an attempt to sway readers' thoughts to doing the will of the advertiser's message. This clause compels the audience to a particular behavioral pattern. Nonetheless, it is left for addressees to accept or reject the message of the addresser. I might illustrate that command by drawing from a situation where the euphemized Drink responsibly is on the assumption that every consumer of Guinness is expected to drink an average of two bottles of the beverage in a day (DALAMU, 2018c). However, a consumer might drink four bottles per day. In that regard, the counsel of Drink responsibly has been rejected. Invariably, every reader of the message determines the actualization of the proposal of the advertising creator to consumers. Drink responsibly seems to me as a way of paying lip service to a policy against drunkenness.

Apart from Text 9b, which is a complete simple clause, The beer without equal, as in Text 9a, and Guinness the power of Naija, as in Text 9c, are chopped up. The ellipsis observed influences the orthographic clause of The beer without equal to function in a similar domain of Residue with Drink responsibly. Although the two clauses are Residues, their functional spheres are partially dissimilar. The grammatical semiosis of Text 9a operates as the Complement - The beer and the Adjunct - without equal. Text 9b exercises a slightly different dimension in the sense that Drink is the Predicator and responsibly is the Adjunct. Going back to the terminology of ellipsis in both 9a and 9c, [Guinness is] could suffice as the fragmented Subject + Finite from the clause. These suggestive elements will produce a full-fledged clause of [Guinness is] the beer without equal. The advertiser removes only the Finite, is, from 9c. If one supplies the grammatical "overture" to the clause, it would produce a simple clause of Guinness [is] the power of Naija. This shows that the advertising business focuses on pieces of information that are highly relevant to the product advertised to the public. One could pinpoint the grammatical meaning potential of 9c in the spheres of the Subject-Guinness, the Complement - the power, and the Adjunct - of Naija. One might stress from a multimodal point of view that the erected bottle of Guinness is a partial non-verbal mode that takes the place of ellipsis in Text 9a.

In corollary, the Guinness ad contains three clauses; however, the messages are literally of two clauses. The beer without equal and Guinness the power of Naija explain some characteristics of Guinness whereas Drink responsibly shines some lights on the behavior expected from consumers. In that regard, the Guinness management team expects consumers to be held 
accountable for their deeds. That means consumers must be reliable and trustworthy. The beer is an alcoholic drink; yet, drinkers must exercise rational conduct, involving a degree of personal accountability. Drink responsibly is a piece of advice as well as an acquitter that exonerates the company from consequences of excess consumption of Guinness. Whether legally or politically or ethically, every consumer is answerable to getting drunk from Guinness through an undue indulgence of personal appetites or gratification. The copywriter creates an insinuation in Text $9 \mathrm{a}$ with a negative polarity of without. The preposition introduces the lexicon, equal. Without equal, from the standpoint of the publicist, is an accompaniment projecting Guinness as The beer that does not have the same value with any other beer in the market place. That demonstrates that Guinness is not only of a different identity; The beer is also of a high quality that does not need a comparison. I could add, in that respect, that Guinness has occupied a consumption trajectory where the juxtaposition of its features has become an impossible task. Therefore, it is probable that The beer is adequate in terms of external stances and internal contents. Such capable omens have nullified Guinness uniformity of any weight with any other alcoholic drink. After all, Guinness is black, perhaps, unlike many other beers in the world. Who knows whether it is the seeming blackness that provides strength of high intensity to Nigerian consumers as rightly exemplified that Guinness [is] the power of Naija.

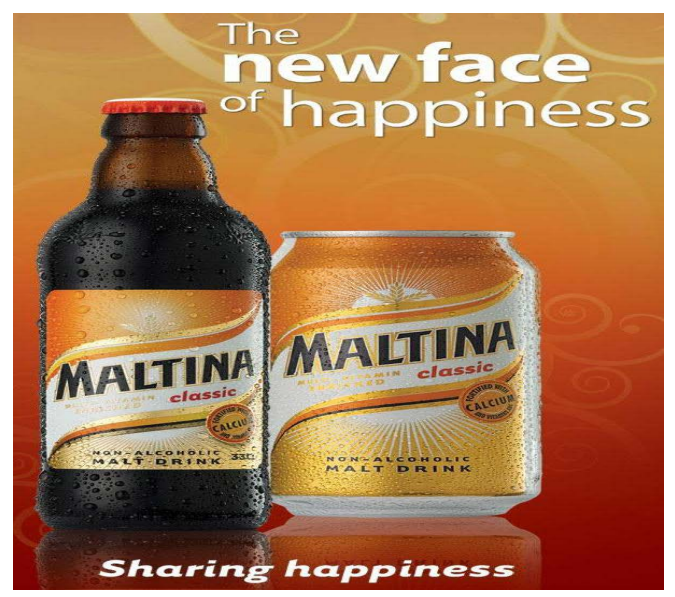

Ad 10 


\begin{tabular}{|l|l|}
\hline The new face & of happiness \\
\hline Complement & Adjunct \\
\hline Residue \\
\hline
\end{tabular}

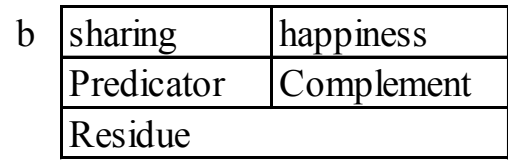

Text 10

Text 10 has two propositions. The first is The new face of happiness; the second is sharing happiness. With those indistinguishable selfsame traits, both Texts $10 \mathrm{a}$ and $10 \mathrm{~b}$ perform constitutive functions. The fundamental relies on the role of commodity that the addresser (communicator) initiated. That is, the communicator gives information to the addressees (readers) about some features of Maltina ${ }^{\circledR}$. Thus, no action is expected from the readers of the ad. Although Texts $10 \mathrm{a}$ and $10 \mathrm{~b}$ are declarative simple clauses, their operational domains are within the potential of Residue, which are apparently similar to Text 9a. The argument is owing to the fact that The new face of happiness and sharing happiness are disjunctive grammatical wordings. The composition, Maltina is, is most likely the eliminated Subject + Finite from the two clauses. In that perspective, the full-stretch of the clauses are [Maltina is] the new face of happiness and [Maltina is] sharing happiness. The Maltina bottle and can are modes that stand for the fragmented portions. Furthermore, it seems that the advertiser wisely informs readers to behold The new face of happiness and at the same time, on the same spot, to share happiness with others. Therefore, there is a mutual alternation between Maltina and happiness. As a result of that characteristic reciprocity, happiness is the referent for Maltina (WILLIAMSON, 1978). The communication switch positions the beverage not only as fortuitously elegant, but also as a drink providing emotional bliss for its consumers.

Besides the Complement, happiness, intermingled with Maltina, the advertising creator deploys The face as an indicator of reinvigoration that the product has undergone. The nominal group, The new face, refreshes the target audience about something unfamiliar in the posture of the beverage. In addition to the content, it seems that the appearances of the bottle and the can, along with both labels and the bottle's crown cork, are refreshingly different. This is because those promotional facilities are classically recent phenomena. The advertiser, I could submit, employs the innovativeness of the product's visibility to human perceptions and the joy desired from the content to convince the public toward patronization. On the one hand, 
the felicity received from the consumption serves as a facility to provoke readers to drink Maltina as well as sharing the product for/with others. On the other hand, the advertiser might share happiness with consumers, perhaps, to promote Maltina. These factors, as the advertiser's claims, are a channel of obtaining good fortune of satisfaction for consumers.

\section{Results}

The present study translates the analysis in Texts 1,2,3-10 to Table 2, Figure 3, and Figure 4. The goal of the operations is to indicate the semiosis items as examined in Texts 1, 2,3-10 above in terms of lexemic artifact resources and role initiation recurrences.

TABLE 2 - Recurrence of semiosis items

\begin{tabular}{|c|c|c|c|c|c|c|c|c|c|c|c|c|}
\hline $\begin{array}{c}\text { Mood } \\
\text { Resources }\end{array}$ & $\begin{array}{l}\text { Semiosis } \\
\text { Items }\end{array}$ & $\begin{array}{c}\text { Text } \\
1\end{array}$ & $\begin{array}{c}\text { Text } \\
2\end{array}$ & $\begin{array}{c}\text { Text } \\
3\end{array}$ & $\begin{array}{c}\text { Text } \\
4\end{array}$ & $\begin{array}{c}\text { Text } \\
5\end{array}$ & $\begin{array}{c}\text { Text } \\
6\end{array}$ & $\begin{array}{c}\text { Text } \\
7\end{array}$ & $\begin{array}{c}\text { Text } \\
8\end{array}$ & $\begin{array}{c}\text { Text } \\
9\end{array}$ & $\begin{array}{c}\text { Text } \\
10\end{array}$ & Total \\
\hline \multirow[t]{3}{*}{ Mood } & Subject & 1 & 0 & 1 & 1 & 4 & 1 & 1 & 1 & 1 & 0 & 11 \\
\hline & Finite & 0 & 0 & 1 & 1 & 5 & 1 & 1 & 1 & 0 & 0 & 10 \\
\hline & Modal Adjunct & 0 & 0 & 0 & 0 & 0 & 0 & 1 & 0 & 0 & 0 & 1 \\
\hline \multirow[t]{3}{*}{ Residue } & Predicator & 0 & 1 & 7 & 3 & 5 & 6 & 1 & 2 & 1 & 1 & 27 \\
\hline & Complement & 1 & 1 & 8 & 3 & 6 & 6 & 0 & 2 & 2 & 2 & 31 \\
\hline & Adjunct & 1 & 1 & 2 & 1 & 7 & 9 & 1 & 3 & 2 & 1 & 28 \\
\hline \multicolumn{2}{|c|}{ Minor Clause } & 0 & 0 & 0 & 0 & 0 & 0 & 0 & 1 & 0 & 0 & 1 \\
\hline
\end{tabular}

Table 2 reveals the ExxonMobi ${ }^{\mathbb{R}}$ ad of Text 5 as containing the highest verbal artifact density. The lexemic density indicates that the pictorial modes do not take preeminence in the ad. Following Leech (1966), the excessive lexemes might hinder the effectiveness of the ExxonMobil ad, owing to the constraint of memorability (KELLARIS; CLINE, 2007; MAI, L-W; SCHOELLER, 2009; YING, 2011). The Airte ${ }^{\circledR}$ ad of Text 6, Union Bank ${ }^{\circledR}$ ad of Text 3 , and $F C M B^{\circledR}$ ad of Text 8 are next to that in the textual density deployment. The Pepsi ${ }^{\mathbb{B}}$ ad of Text 4 also pulls some textual weights with nine semiosis elements. Others, such as Peak ${ }^{\circledR}$ ad of Text 1 , Star Lite ${ }^{\circledR}$ ad of Text 2, Harp $^{\circledR}$ ad of Text 7, Guinness ${ }^{\circledR}$ ad of Text 9, and Maltina ${ }^{\circledR}$ ad of Text 10 exhibit lower textual density as illustrated in Figure 3. By implication, pictorial and textual modes interact effectively in those ads, often making 
non-verbal references to recover verbal elements. However, the role initiation of commodity is not in parallel with the recurrence of the textual artifact as shown later in Figure 4.

FIGURE 3 - Frequency of the textual artifact resources

\begin{tabular}{|l|c|}
\hline Semiosis Itens & Frequency \\
\hline Subject & 11 \\
\hline Finite & 10 \\
\hline Modal Adjunct & 1 \\
\hline Predicator & 27 \\
\hline Complement & 31 \\
\hline Adjunct & 28 \\
\hline Minor Clause & 1 \\
\hline
\end{tabular}

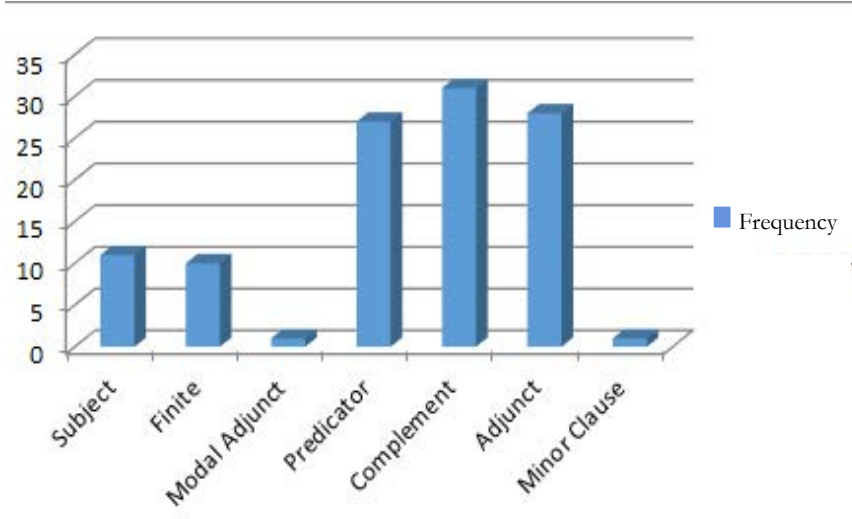

As demonstrated in Figure 3, the Complement, the Adjunct, and the Predicator record the highest points of 31, 28, and 27. By implication, the calibrations show that the advertisers focus on the use of the Residue to convince the target audience more than the Mood. This is because the product's image, which is the non-verbal information, has the capacity to function as the Mood. Moreover, Figure 3 reports the Subject and Finite, which are core devices of Mood, as functioning 11 and 10 times, respectively. Both the Modal Adjunct and the Minor Clause function insignificantly in the graph representation in Figure 3. 
FIGURE 4 - Frequency of the role initiation resources

\begin{tabular}{|c|c|c|c|c|c|c|c|c|c|c|}
\hline Products & 苞 & $\begin{array}{l}\text { 号 } \\
\text { 苞 }\end{array}$ & 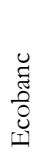 & صू & 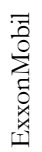 & 焉 & 墨 & Uي & 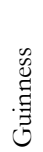 & $\Xi$ \\
\hline Commodity Initiated & 1 & 1 & 9 & 5 & 7 & 7 & 1 & 4 & 3 & 2 \\
\hline
\end{tabular}

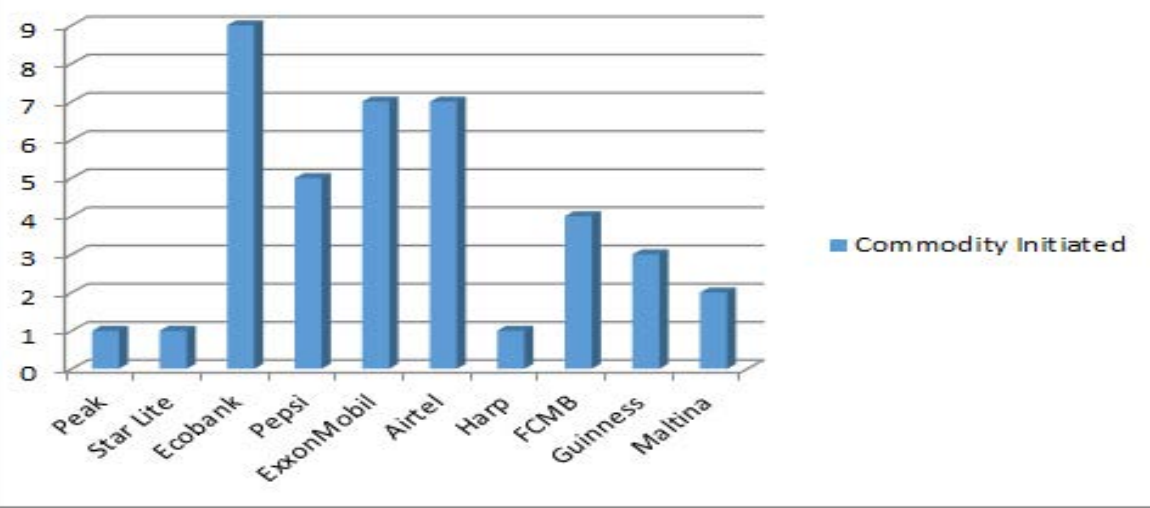

The illustration of the role initiation of commodity in Figure 4 (transferred from Table 1) indicates that Union Bank deploys eight clauses of different communicative capacities to persuade readers. ExxonMobiland Airtel are next in such sensitizing behavior with seven clauses respectively. In addition, Pepsi employs five clauses, while FCMB uses four clauses as motivational role initiating commodities. As Guinness and Maltina use three and two clauses to excite the audience, Peak and Star Lite tend to influence readers with one clause each. Therefore, one could negotiate certain things from the aforementioned parameters. It is deducible that the frequency of the textual artifacts does not in any way determine the frequency of the commodities that the initiators of the exchange deploy to interact with the viewers as clarified in Figures 3 and 4. Moreover, quickly, some semiosis items are fragmented to suit advertising purposes of, perhaps, brevity as the investigation has earlier expounded in the discussion segment.

Table 3, below, further illustrates the nature of role initiatives in the ads. 
TABLE 3 - Recurrence of the nature of role initiatives

\begin{tabular}{l|c|c|c|c|c|c|c|c|c|c|c}
\hline \multicolumn{1}{c|}{ Role Initiatives } & $\begin{array}{c}\text { Text } \\
1\end{array}$ & $\begin{array}{c}\text { Text } \\
2\end{array}$ & $\begin{array}{c}\text { Text } \\
3\end{array}$ & $\begin{array}{c}\text { Text } \\
4\end{array}$ & $\begin{array}{c}\text { Text } \\
5\end{array}$ & $\begin{array}{c}\text { Text } \\
6\end{array}$ & $\begin{array}{c}\text { Text } \\
7\end{array}$ & $\begin{array}{c}\text { Text } \\
8\end{array}$ & $\begin{array}{c}\text { Text } \\
9\end{array}$ & $\begin{array}{c}\text { Text } \\
10\end{array}$ & Total \\
\hline Giving information & 1 & 0 & 1 & 4 & 7 & 3 & 1 & 3 & 2 & 2 & 24 \\
\hline Giving goods-\&-services & 0 & 0 & 0 & 0 & 0 & 0 & 0 & 0 & 0 & 0 & 0 \\
\hline Demanding information & 0 & 0 & 0 & 0 & 0 & 0 & 0 & 0 & 0 & 0 & 0 \\
\hline $\begin{array}{l}\text { Demanding goods-\&- } \\
\text { services }\end{array}$ & 0 & 1 & 8 & 2 & 0 & 4 & 0 & 0 & 0 & 0 & 15 \\
\hline
\end{tabular}

I have translated the elements of Table 3 to a table and graph, as shown in Figure 5, in order to show the frequency of the nature of the role initiatives in the ads.

FIGURE 5 - Frequency of the nature of role initiatives

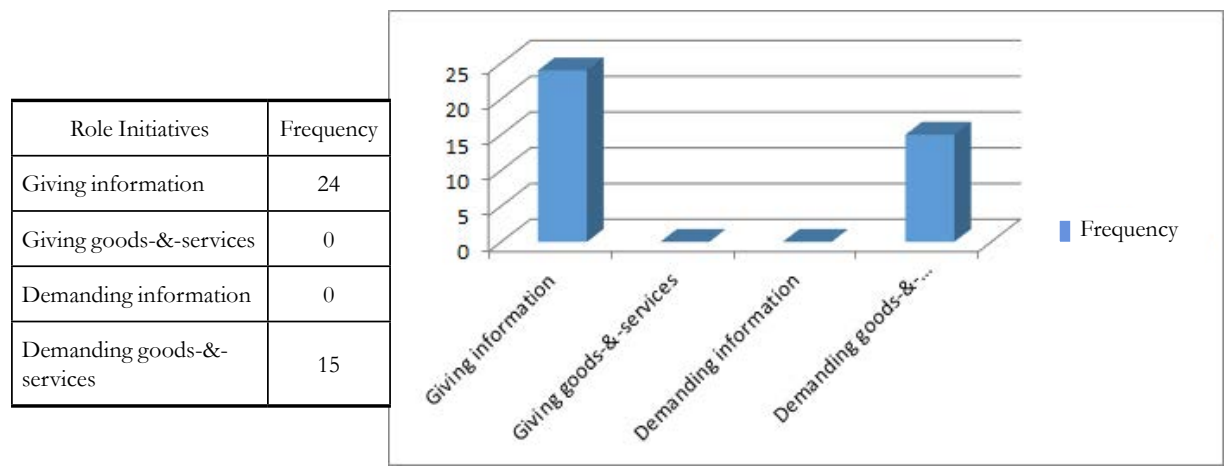

Figure 5 exhibits that giving information (statement), with a value of 25 points, dominates the messages of the advertising communications of Pepsi, ExxonMobil, FCMB, etc. Demanding goods-\&-services (command), for instance in Star Lite, Union Bank, Airtel, etc., has a frequency of 15 points, portraying the role initiative construct in the last position. Giving goods-\&-services (offer) and demanding information (question), according to Figure 5, have no communicative place in all the ads. Thus, all of the advertisers prefer making statements and commanding than modulating and questioning the audience to consumption.

Given the questions asked earlier in the introductory section of this paper, the present study therefore deduces the following: 
i. Figure 3 manifests the Complement, the Adjunct, and the Predicator of 31,28 , and 27 points as the highest levels of the lexemic density. These records are followed by the Subject and the Finite of 11 and 10 recurrent values respectively. Though the inconsequential Modal Adjunct and Minor Clause, recording one point each, are rarely deployed in the lexemic density. Upon this backdrop, I might submit that the advertisers employ textual artifact resources of Residue more often than of Mood.

ii. The 10 advertising communications in this study demonstrate different role initiatives. As illustrated in Figure 4, Ecobank, ExxonMobile, and Airtel display nine, seven, and seven role initiation resources, though of different kinds. Pepsi, FCMB, Guinness, and Maltina use their role initiation resources in the sequences of five, four, three, and two. However, Peak, Star Lite, and Harp employ one resource each for the role initiation. Halliday and Matthiessen (2014) describe the commodity that interactants initiate as giving information, giving goods- $\&$-services, demanding information, and demanding goods- $\&$-services. Thus, the following sequences define the nature of the role initiatives in the 10 ads considered, as illustrates in Table 3 and Figure 5. Giving information operates one time each in Texts 1, 3, and 7; two times each in Texts 1 and 10; three times each in Texts 6 and 8 ; four times in Text 4; and one time in Text 5 . Demanding goods- $\&$-services functions one time each in Texts 2 and 9; two times in Text 4; four times in Text 6; and eight times in Text 3. It is worth stressing that some of these statements are fragmented as one can see, for instance, in Texts 3c, 4a, 9a, and 10a

iii. The advertisers employ several contextual devices of sport, as in Ad 1; atmosphere, as in Ads 2, 7, and 10; digital context, as in Ad 3; and entertainment, as in Ad 4. Other persuasive facilities are traditional celebration as in Ad 5, medical context as in Ad 6, religion as in Ad 8, and the culture of superiority as in Ad 10.

iv. Observations indicate interactional intersections between verbal and non-verbal texts of the ads. Among others, Ad 1 exhibits the pictorial modes of the Peak Milk container to replace the punctuated part of official milk of the Super Eagles, as the Guinness bottle substitutes the fragmented segment of The beer without equals, and the Maltina bottle can connect to The new face of happiness. Feel the chill here in Ad 2 reveals the hazy and cool atmosphere around the Star Lite, while *826\# of Ad 3 is a mode that intersects the verbal elements of The new Union Bank USSD code. Ad 4 creates a form of triangular intersectional interaction in 
the word Widrkid to intersect the iconic image, and the pictorial image connects the bottle of Pepsi in the Widqkid's hand; in turn, the Pepsibottle intersects with other brands of 7 Up, Mirinda, and Teem, positioned below the advertising framework. The traditional postures in Ad 6 are modes that replace the disjunctive structures of Celebrating Akwa Ibom at 30 in the same way that the whitish foam of Harp in Ad 7 interacts with the verbal mode, Promise of perfection. Ad 7 uses the rosary and a container of fruits to signify a worship instrument and food for the celebration, which is revealed in the verbal mode of Eid-el-Fitr.

\section{Conclusion}

The mood system resources and wordings in advertising function in a commonplace of text. The text functions as the artifact as well as a communicative facility to the target audience. Moreover, the text serves as the specimen for the Halliday's mood resources with a particular theoretical clime. Both the artifact and the specimen, as demonstrated in the study, illuminate readers as to the meaning potential of the ads in terms of structural bearings and semantic explorations.

Observations show, in parallel to the mood system, that Questions either as polar or elemental (demanding information) and Offer (giving goods-\&-services) do not operate in all the ads considered in this study. That comment invariably demonstrates that Statement (giving information) and Command (demanding goods- $\&$-services) dominate the spheres of the interact between the addresser (advertiser) and the addressee (readers). The relevance of these textual (artifact) behaviors is that advertisers hardly use Question and Offer in their communications. Rather, advertising professionals tend to encourage consumers through Statements and Commands. That is, advertisers do their communicative exchange(s) of sensitization in the forms of half-way propositions and half-way proposals, achieving constitutive and ancillary functions. Apart from few declarativestatements that appear in their fullness of structures (We're prond to be part of your history, as you consolidate on the blessing of Ramadan, etc.), a handful of the declaratives are punctuated (official milk of the Super Eagles, *826\#, No shakin', From all of us at FCMB, The beer without equal, etc.). Most of the disjunctive devices are nominal group facilities in the ramifications of Complements and Adjuncts. Probably, the exemption of the nominal items provides a 
leeyway for non-verbal modes to regenerate the fragmentations. However, the analyst seems unable to consistently notice many disjunctions in the imperative-commands.

There are some contextual areas, the investigation reveals, which operate as the focus of the advertising communications. For a purpose of persuasion, the "narrators" partner consumers in cultural treasures (Celebrating Akwa Ibom at 30), sporting activities (Peak official milk of the Super Eagles), religious values (Happy Eid-el-Fitr), and musical tenets (Pepsi, Wiףkid). The product's features as in its coldness (Feel the chill here), its strength (Guinness the power of Naija), and its volume and price (50cl back@100) play some resonating roles in the persuasive thoughts. The interactions also adopt personal gains such as a digital convenience (Do more with *826\#), medical benefit (Dial $67777 . .$. to speak to a doctor), and drinking satisfaction (best enjoyed with Harp, sharing happiness). Furthermore, the application of textual exaltations also drives the consumption negotiation moments. The study realizes those key stimulating factors in Promise of perfection, The beer without equal, The new face of happiness, etc. as signifiers of flawlessness, most successful entity, and novelty.

Fundamentally, I might deduce, among other things, that the communicator uses the image of the Peak Milk container to intersect with the punctuated verbal structures, with a slight green-Nigerian national color in the background, in order to propel readers to consumption. Ad 4, Ad 5, Ad 9, and Ad 10 display a similar communicative pattern. Ad 2 exhibits the 'chill' image around the bottle of Star Lite to connote the verbal content, chill, inscribed below the advertising framework. The advertiser uses a meme wearing a stethoscope to appear as a doctor on a telephone. The non-verbal elements represent a doctor as written in the plate to be in operation. One could observe a sign of communicative energy, in the form of the emission of rays, flowing out of the telephone, perhaps, intending to connect people who need medical attention. The foaming behavior of the beer in Ad 7 demonstrates the nature of Harp, as repetitively shown in the construction. FCMB employs the verbal facility - Happy Eid-el-Fitr - and non-verbal - a container of fruits and a cluster of rosary to identify and communicate the Muslim faithfuls. 


\section{References}

ADETUGBO, A. English Phonetics: A Course Text. Yaba: University of Lagos Press, 1997. 164p

ALOUSQUE, I. S. Visual Wine Metaphor and Metonymy in Ads. Procedia - Social and Behavioral Sciences, Netherland, v. 173, p. 125-131, 2015. Doi: https://doi. org/10.1016/j.sbspro.2015.02.041. Available at: https://core.ac.uk/download/ pdf/82043392.pdf. Retrieved on: 10 Jan. 2019.

ASHONG C.; OGARAKU C. H. Content Preference Among Online and Hardcopy Newspaper Readers in Imo State. Journal of New Media and Mass Communication, [S.l.], v. 4, n. 1, p. 1-15, 2017. Doi: https://doi.org/10.18488/ journal.91/2017.4.1/91.1.1.15

AWONUSI, V. O. Invitation as style and discourse in Nigerian English. In: DARAMOLA, A.; OLUGASA, O. (ed.). Literature and Language: A Drama of Life - Festschrift in Honor of Z. A. Adejumo. Lagos: BPrint. 2007. p. 86-97.

BAILEY, R.; COPE, E.; PARNELL, D. Realising the benefits of sports and physical activity: the human capital model. Retos, Spain, v. 28, p. 147-154, 2015.

BEZEMER, J.; JEWITT, C. Multimodal analysis: key issues. In: LITOSSELITI, L. (ed.). Research Methods in Linguistics. New York, NY: Continuum, 2010. p. 180-197.

BLOOR, T.; BLOOR, M. The Functional Analysis of English. Great Britain: Hodder, 2004. 315p. Doi: https://doi.org/10.4324/9780203774854

BRIERLEY, S. The Advertising Handbook. London: Routledge, 1995. 276p.

BUTT, D., FAHEY, R., SPINKS, S.; YALLOP, C. Using Functional Grammar: An Explorer's Guide. Macquarie University: National Centre for English Language Teaching and Research, 1995. p. 2-14.

CHOMSKY, N. Aspects of the Theory of Syntax [Aspects]. Cambridge, Mass: MIT Press, 1965. Doi: https://doi.org/10.21236/AD0616323

CLARK, J.; YALLOP, C. An Introduction to Phonetics and Phonology. Victoria, Australia: Blackwell Publishing. 1995. 468p.

CLINTON, H.; KAINE, T. Stronger Together. New York: Simon and Schuster, 2016. COOK, G. The Discourse of Advertising. New York: Routledge, 2001. 255p. Doi: https://doi.org/10.4324/9780203978153

DALAMU, T. O. A Discourse Analysis of Language Choice in $M T N^{\circledR}$ and Etisalat ${ }^{\circledR}$ Advertisements in Nigeria. 2017. Dissertation (Ph.D.) - University of Lagos, Yaba, Nigeria, 2017. Available at: http://www.isfla.org/Systemics/Print/Theses.html. Retrieved on: 22 Jan. 2019. 
DALAMU, T. O. A Functional Approach to Advertisement Campaigns in AngloNigerian Pidgin. Studies in Linguistics, Daessung-ro, v. 44, p. 155-185, 2017b. Doi: https://doi.org/10.17002/sil..44.201707.155

DALAMU, T. O. Exploring Advertising Text in Nigeria Within the Framework of Cohesive Influence. Styles of Communication, Bucharest, v. 10, n. 1, p. 74-97, 2018 a.

DALAMU, T. O. English Language Development in Nigerian Society: A Derivative of Advertising Communications. Complutense Journal of English Studies, Madrid, v. 26, p. 263-286, 2018b. Doi: https://doi.org/10.5209/CJES.56940

DALAMU, T. O. Euphemism: The Commonplace of Advertising Culture. Acta Scientiarum. Language and Culture, Maringá, v. 40, n.2, p. 1-15, 2018c. Doi: https:// doi.org/10.4025/actascilangcult.v40i2.41107

DE BEAUGRANDE, R. Linguistic Theory: The Discourse of Fundamental Works. London: Longman, 1991. 403p.

DE BEAUGRANDE, R.; DRESSLER, W. Introduction to Text Linguistics. London: Longman, 1981. 286p. Doi: https://doi.org/10.4324/9781315835839

EGGINS, S. Introduction to Systemic Functional Linguistics. London: Continuum, 2004. $384 \mathrm{p}$.

EGGINS, S.; SLADE, D. Analysing Casual Conversation. London: Equinox, 1997. 333p.

FAIRCLOUGH, N. Analysing Discourse: Textual Analysis for Social Research. New York: Routledge, 2003. 270p. Doi: https://doi.org/10.4324/9780203697078

FONTAINE, L. Analysing English Grammar: A Systemic Functional Introduction. Cambridge: Cambridge University Press, 2013. 294p. Doi: https://doi. org/10.1017/CBO9781139026635

FONTAINE, L.; BARTLETTT, T.; O'GRADY, G. (ed.). Systemic Functional Linguistics: Exploring Choice. Cambridge: Cambridge University Press, 2013. 533p. Doi: https:// doi.org/10.1017/CBO9781139583077

FORCEVILLE, C. Pictorial Metaphor in Advertising. London: Routledge, 1996. 233p. Doi: https://doi.org/10.4324/9780203272305

FORCEVILLE, C. Review of Jewitt, C. (ed.). The Routledge Handbook of Multimodal Analysis (Routledge, 2009). Journal of Pragmatics, Amsterdam, v. 42, n. 9, p. 2606-2608, 2010. Doi: https:// doi.org/10.1016/j.pragma.2010.03.003

GEIS, M. L. The Language of Television Advertising. London: Academic Press, 1982. $257 \mathrm{p}$. 
GEORGE, C. C. Influence of Advertising on the Sale of Shopping Goods in Bayelsa State. Thesis (M.Sc.) - University of Nigeria, Nsukka, 2010. Available at: http://www. unn.edu.ng/publications/files/images/GEORGE,\%20COMFORT\%20.C.pdf. Retrieved on: 20 Jan. 2019.

GEROT, L.; WIGNELL, P. Making Sense of Functional Grammar. Sydney: Gerd Stabler Antipodean Educational Enterprises, 1994. 264p.

GIESZINGER, S. The History of Advertising Language. Frankfurt: Peter Lang GmbH, 2001.363p.

GODDARD, A. The Language of Advertising. London: Routledge, 2002. 131p.

GREGORY, M.; CARROLL, S. Language and Situation. Boston: Routledge \& Kegan, 1978. 113p.

HALLIDAY, M. A. K. An Introduction to Functional Grammar. Great Britain: Arnold, 1995. 356p.

HALLIDAY, M. A. K. On Grammar. Edited by Jonathan J. Webster. New York, NY: Continuum, 2002. 442p. (Collected Works of M.A.K. Halliday, v. 1)

HALLIDAY, M. A. K.; HASAN, R. Cohesion in English. England: Longman, 1976. 374p.

HALLIDAY, M. A. K.; MATTHIESSEN, C. Systemic Functional Grammar: a First Step into the Theory. 1997. Available at: https://www.researchgate. net/profile/Christian_Matthiessen/publication/265398862_SYSTEMIC_ FUNCTIONAL_GRAMMAR_A_FIRST_STEP_INTO_THE_THEORY/ links/54b513ef0cf28ebe92e4bacf.pdf. Retrieved on: 12 Apr. 2010.

HALLIDAY, M. A. K.; MATTHIESSEN, C. An Introduction to Functional Grammar. Great Britain: Hodder Arnold, 2004. 689p.

HALLIDAY, M. A. K.; MATTHIESSEN, C. Halliday's Introduction to Functional Grammar. Abingdon, Oxon: Routledge, 2014. 786p. Doi: https://doi. org/10.4324/9780203783771

HAN, K. W.; HONG-LIM, C. Use of Ambiguity in Advertising Creativity: A CrossCultural Perspective. Indian Journal of Science and Technology, India, v. 8, n. 26. p. 1-5, 2015. Doi: https://doi.org/10.17485/ijst/2015/v8i26/87112

HERMERÉN, L. English for Sale: A Study of the Language of Advertising. Lund: Lund University Press, 1999. 201p.

HOEY, M. P. Textual Interaction. London: Routledge, 2000. 248p.

HUI, A. Aphorism: A Theory of Aphorism from Confucius to Twitter. New Jersey: Princeton University Press, 2019. 247p. Doi: https://doi.org/10.2307/j.ctv941t7d 
JEWITT, C. (ed.). The Routledge Handbook of Multimodal Analysis. London: Routledge, 2009.340p.

JEWITT, C.; BEZEMER, J.; O'HALLORAN, K. Introducing Multimodality. London: Routledge, 2016.220p.

KELLARIS, J. J.; CLINE, T.W. Humor and ad memorability: on the contributions of humor expectancy, relevancy, and need for humor. Psychology \& Marketing, New York, v. 24, n. 6, p. 497-509, 2007. Available at: https://onlinelibrary.wiley. com/doi/pdf/10.1002/mar.20170. Retrieved on: 23 Jan. 2019. Doi: https://doi. org/10.1002/mar.20170

KRESS, G. Multimodality: A Social Semiotic Approach to Contemporary Communication. New York: Routledge, 2010. 205p. Doi: https://doi. org/10.4324/9780203970034

KRESS, G. What is Mode? In: JEWETT, C. (ed.). The Routledge Handbook of Multimodal Analysis. New York, NY: Routledge, 2009. p. 54-67.

KRESS, G.; VAN LEEUWEN, T. Reading Images: The Grammar of Visual Design. 2nd Ed. London, GB: Routledge, 2006. 288p. Doi: https://doi. org/10.4324/9780203619728

LAGERWERF, L. Deliberate Ambiguity in Slogans: Recognition and Appreciation. Document Design, Amsterdam, v. 3, n. 3, p. 245-260, 2002. Doi: https://doi. org/10.1075/dd.3.3.07lag. Available at: https://ris.utwente.nl/ws/files/6761164/ Lagerwerf02deliberate.pdf. Retrieved on: 13 Jan. 2019.

LEECH. G. English in Advertising: A Linguistic Study of Advertising in Great Britain. London: Longman, 1996. 210p.

LEMKE, J. L. Multiplying Meaning: Visual and Verbal Semiotics in Scientific Text. In: MARTIN, J. R.; VEEL, R. (ed.). Reading Science: Critical and Functional Perspectives on Discourses of Science. London: Routledge, 1998. p. 87-113.

LEO, O. N. E.; NKIRU, C. E.; ANIEBO, C. S. Evaluation of Newspaper Reading Habits of Youths in Anambra State, Nigeria. New Media and Mass Communication, [S.l.], v. 37, p. 63-72, 2015.

MAI, L-W.; SCHOELLER, G. Emotions, Attitudes and Memorability Associated with TV Commercials. Journal of Targeting Measurement and Analysis for Marketing, [S.l.], v. 17, n. 1, p. 55-63, 2009. Doi: https://doi.org/10.1057/jt.2009.1

MALMKJAER, K. (ed.). The Linguistics Encydopedia. London: Routledge, 2004. 643p. Doi: https://doi.org/10.4324/9780203644645 
MARTIN, J. R. English Text: System and Structure. Amsterdam: John Benjamins, 1992. 620p. Doi: https://doi.org/10.1075/z.59

MARTIN, J. R.; MATTHIESSEN, C.; PAINTER, C. Working with Functional Grammar. London: Arnold, 1997.306p.

MARTIN, J. R.; ROSE, C. Working with Discourse: Meaning Beyond the Clause. New York: Bloomsbury Academy, 2005. 293p.

MATTHIESSEN, C.; TERUYA, K.; LAM, M. Key Terms in Systemic Functional Linguistics. London: Continuum, 2010. 308p.

MESSARIS, P. Visual Literacy. Image, Mind, \& Reality. Boulder, CO: Westview Press, 1994. 224p.

MESSARIS, P. Visual Persuasion: The Role of Images in Advertising. Thousand Oaks, CA: Sage, 1997. 320p.

MYERS, K. Under Stains: The Sense and Seduction of Advertising. Surrey: The Gresham Press, 1986.157p.

MYERS, G. Words in Ads. London: Arnold, 1994. 222p.

NIXON, S. Hard Looks: Masculinities, the Visual Practices of Consumption. London: UCL Press, 1996. 241p. Doi: https://doi.org/10.1007/978-1-349-61442-4

NORVIG, P. Multiple Simultaneous Interpretations of Ambiguous Sentences, p. 1-6, nd. Available at: https:/ / norvig.com/mult-amb.pdf. Retrieved on: 14 Jan. 2019.

PÉREZ-SOBRINO, P. Multimodal Metaphor and Metonymy in Advertising: A Corpus-Based Account. Metaphor \& Symbol, London, v. 31, n. 2, p.1-18, 2016. Doi: https://doi.org/10.1080/10926488.2016.1150759

O'HALLORAN, K. L. Visual Semiosis in Film. In: O'HALLORAN, K. L. (ed.). Multimodal Discourse Analysis: Systemic Functional Perspectives. London: Continuum, 2004. p. 109-113.

PACKARD, V. The Hidden Persuader. Brooklyn: IG Publishing, 2007. 240p.

RAVELLI, L. Getting Started with Functional Analysis of Texts. In: UNSWORTH, L. (ed.). Researching Language in Schools and Communities. London: Continuum, 2000, p. 27-63.

REEVES, R. Reality in Advertising. New York: Knopt, Alfred Inc., 1970. 159p.

RICHARDS, J.; PLATT, J.; WEBER, H. Longman Dictionary of Applied Linguistics. London: Longman, 1997. 323p.

ROSSITER, J.; PERCY, L. Advertising and Promotion Management. New York: McGraw-Hill, 1987. 672p. 
SWEET, H. A New English Grammar: Logical and Historical. Oxford, GB: Clarendon, 1891.

THESUN. Youths Laud Declaration of Oct. 6 as Wizkid Day by Governor of Minnesota, 9 Oct 2018. Available at: https://www.sunnewsonline.com/youths-laud-declaration-of-oct6-as-wizkid-day-by-governor-of-minnesota/. Retrieved on: 9 Oct. 2018.

THOMPSON, G. Introducing Functional Grammar. Great Britain: Hodder Arnold, 2004. 300p.

THOMPSON, G. Introducing Functional Grammar. Abingdon, Oxon: Routledge, 2014. 328p. Doi: https://doi.org/10.4324/9780203785270

TSENG, C. Coherence and Cohesive Harmony in Filmic Text. In: UNSWORTH, L. (ed.). Multimodal Semiotics: Functional Analysis in Context of Education. New York: Continuum, 2008. p. 87-104.

VESTERGAARD, T.; SCHRODER, K. The Language of Advertising. Oxford: Basil Blackwell, 1985. 182p.

WANG, J. Brand New China: Advertising, Media and Commercial Culture. Cambridge, Massachusetts: Harvard University Press, 2008. 411p. Doi: https:// doi.org/10.4159/9780674044821

WEISSER, M. Features of a Text, 2005. p. 1-3. Available at: http://martinweisser. org/courses/intro/textling.html. Retrieved on: 23 Jun. 2017.

WHO. Promoting Sport and Enhancing Health in European Union Countries: A Policy Content Analysis to Support Action. WHO Regional Office, Scherfigsvej, Copenhagen: Denmark. 2011. 68p.

WILLIAMSON, J. Decoding Advertising: Ideology and Meaning in Advertising. New York: Marion Boyars, 1978. 180p.

YING, C. Memorability in the Translation of Advertising Texts: Analysis from the Perspective of Presupposition. Thesis (PhD) - City University of Hong Kong, Hong Kong, 2011. Available at: http://lbms03.cityu.edu.hk/theses/c_ftt/phdctl-b4086084xf.pdf. Retrieved on: 20 Jan. 2019.

YULE, G. The Study of Language. Cambridge: Cambridge University Press, 1986. 220p.

Data de submissão: 02/12/2017. Data de aprovação: 10/01/2019. 